\title{
2. EXPLANATORY NOTES: ODP LEG 105, BAFFIN BAY AND LABRADOR SEA ${ }^{1}$
}

\author{
Shipboard Scientific Party ${ }^{2}$
}

Standard procedures for both drilling operations and preliminary shipboard analysis of the material recovered during Deep Sea Drilling Project (DSDP) and Ocean Drilling Program (ODP) drilling have been regularly amended and upgraded since drilling began in 1968. In this chapter, we have assembled information that will help the reader understand the basis for our preliminary conclusions and also help the interested investigator select samples for further analysis. This information concerns only shipboard operations and analyses described in the site reports in the Initial Report, or Part A, of the Leg 105 Proceedings of the Ocean Drilling Program. Methods used by various investigators for further shore-based analysis of Leg 105 data will be detailed in the individual scientific contributions published in the Final Report, or Part B, of this volume.

\section{AUTHORSHIP OF SITE REPORTS}

Authorship of the site reports is shared among the entire shipboard scientific party, although the two co-chief scientists and the staff scientist edited and rewrote part of the material prepared by other individuals. The site chapters are organized

${ }^{1}$ Srivastava, S. P., Arthur, M., Clement, B., et al., 1987. Proc. Init. Repts. (Part A), ODP, 105.

2 Ali Aksu, Earth Sciences Department, Memorial University of Newfoundland, St. John's, Newfoundland A1B 3X5, Canada; Michael Arthur (Co-Chief Scientist), Graduate School of Oceanography, University of Rhode Island, Narragansett, RI 02882; Jack Baldauf, Ocean Drilling Program, 1000 Discovery Drive, College Station, TX 77840; Gerhard Bohrmann, Geologisch-Palaeontologisches, Institut und Museum der CAU, Olshausenstr. 40, 2300 Kiel, Federal Republic of Germany; William Busch, Department of Geology and Geophysics, University of New Orleans, LA 70148; Tommy Cederberg, University of Copenhagen, Geological Institute, Oester Voldgade 10, DK-1350, Copenhagen, Denmark; Bradford Clement (Co-Chief Scientist), Ocean Drilling Program, 1000 Discovery Drive, College Station, TX 77840; Michel Cremer, Departement de Géologie et Océanographie, UA 197, Université de Bordeaux I, Avenue des Facultés, 33405 Talence Cedex, France; Kathleen Dadey, Graduate School of Oceanography, University of Rhode Island, Narragansett, RI 02882; Anne De Vernal, GEOTOP, Sciences de la Terre, Universite du Quebec a Montreal, L.P. 8888, Succ "A," Montreal, Quebec H3C 3P8, Canada; John Firth, Department of Geology, Florida State University, Tallahassee, FL 32306; Frank Hall, Graduate School of Oceanography, University of Rhode Island, Narragansett, RI 02882; Martin Head, Department of Geology, University of Toronto, Toronto M5A 1A1, Canada; Richard Hiscott, Earth Sciences Department, Memorial University, St. John's, Newfoundland A1B 3X5, Canada; Rich Jarrard, Lamont-Doherty Geological Observatory, Palisades, NY 10964; Michael Kaminski, WHOI/MIT Joint Program in Oceanography, Woods Hole Oceanographic Institution, Clark 1, Woods Hole, MA 02543; David Lazarus, Woods Hole Oceanographic Institution, Department of Geology and Geophysics, Woods Hole, MA 02543; Anne-Lise Monjanel, Université de Bretagne Occidentale, G.I.S. Océanologie et Géodynamique, 6, Av. Victor le Gorgeu, 29283 Brest Cedex, France; Ole Bjorslev Nielsen, Department of Geology, Aarhus University, DK-8000 Aarhus C, Denmark; Surat P. Srivastava (Co-Chief Scientist), Atlantic Geoscience Centre, Geological Survey of Canada, P.O. Box 1006, Dartmouth, Nova Scotia B2Y A42, Canada; Ruediger Stein, Institute of Petroleum and Organic Geochemistry, KFA Julich, P.O. Box 1913, 5170 Julich, Federal Republic of Germany (current address: Institut fuer Geowissenschaften und Lithosphaeren forschung, Universitaet Giessen, Senckenbergstr. 3, 6300 Giessen, Federal Republic of Germany); Francois Thiebault, Lab. Dynamique Sédimentaire et Structurale, UA 713 UER Sciences de le Terre, Université de Lille I, 59655 Villeneuve D'Ascq Cedex, France; James Zachos, Graduate School of Oceanography, University of Rhode Island, Narragansett, RI 02882; Herman Zimmerman, Department of Geology, Union College, Schenectady, NY 12308 (current address: Division of Polar Programs, National Science Foundation, Washington, D.C. 20550). as follows (authors are listed in alphabetical order in parentheses; no seniority is necessarily implied):

Site Data and Principal Results (Arthur, Srivastava)

Background and Objectives (Arthur, Srivastava)

Operations (Arthur, Srivastava)

Sedimentology (Bohrmann, Cremer, Hiscott, Nielsen, Stein, Thiebault, Zimmerman)

Basement Rocks (Bohrmann, Cremer, Hiscott, Nielsen, Thiebault, Zimmerman)

Biostratigraphy (Aksu, Baldauf, De Vernal, Firth, Head, Kaminski, Lazarus, Monjanel)

Paleomagnetics (Clement, Hall, Jarrard)

Organic Geochemistry (Cederberg, Stein)

Inorganic Geochemistry (Zachos)

Physical Properties (Busch, Dadey)

Sediment-Accumulation Rates (Aksu, Baldauf, Clement, De

Vernal, Firth, Hall, Head, Kaminski, Lazarus, Monjanel)

Downhole Logging (Jarrard)

Seismic Stratigraphy (Arthur and Srivastava)

Summary and Conclusions (Arthur and Srivastava)

Following the text of each site chapter are summary graphic lithologic and biostratigraphic logs, core descriptions ("barrel sheets"), and photographs of each core. Plots of the data obtained from the Gamma Ray Attenuation Porosity Evaluator (GRAPE) device for each of the cores follow the barrel sheets and core photographs.

\section{SURVEY AND DRILLING DATA}

The survey data used for specific site selections are discussed in each site chapter. Short surveys using a precision echo-sounder and seismic profiles were made on JOIDES Resolution approaching each site. All geophysical-survey data collected during Leg 105 are presented in the "Underway Geophysics" chapter (this volume).

The seismic-profiling system consisted of two 80 -in. ${ }^{3}$ water guns; one 400 -in. ${ }^{3}$ water gun; one 300 -in. ${ }^{3}$ air gun, having a hydrophone array designed at Scripps Institution of Oceanography; Bolt amplifiers; two band-pass filters; and two EDO recorders, usually recording at two different filter settings (20-300 and $30-300 \mathrm{~Hz}$ ).

The $3.5-$ and $12-\mathrm{kHz}$ bathymetric data were displayed on Precision Depth Recorder systems. The depths were converted on the basis of an assumed $1463 \mathrm{~m} / \mathrm{s}$ sound velocity. The water depth (in meters) at each site was corrected (1) for the variation in sound velocity with depth using Matthews' (1939) tables and (2) for the depth of the hull transducer $(6.8 \mathrm{~m})$ below sea level. In addition, depths when referred to the drilling-platform level are assumed to be $10.5 \mathrm{~m}$ above the water line.

\section{DRILLING CHARACTERISTICS}

Because water circulation down the hole is open, cuttings are lost onto the seafloor and cannot be examined. The only available information about sedimentary stratification in uncored or unrecovered intervals, other than from seismic data or wirelinelogging results, is from an examination of the behavior of the 
drill string as observed and recorded on the drilling platform. Typically, the harder a layer, the slower and more difficult it is to penetrate. A number of other factors, however, determine the rate of penetration, so it is not always possible to relate drilling time directly to the hardness of the layers. Bit weight and revolutions per minute, recorded on the drilling recorder, influence the penetration rate.

\section{DRILLING DEFORMATION}

When cores are split, many show signs of significant sediment disturbance, including the downward-concave appearance of originally horizontal bands, haphazard mixing of lumps of different lithologies (mainly at the tops of cores), and the nearfluid state of some sediments recovered from tens to hundreds of meters below the seafloor. Core deformation probably occurs during one of three different steps at which the core can suffer stresses sufficient to alter its physical characteristics: cutting, retrieval (with accompanying changes in pressure and temperature), and core handling on deck.

\section{SHIPBOARD SCIENTIFIC PROCEDURES}

\section{Number of Sites, Holes, Cores, and Samples}

ODP drill sites are numbered consecutively from the first site drilled by DSDP Glomar Challenger in 1968. Site numbers are slightly different from hole numbers. A site number refers to one or more holes drilled while the ship is positioned over a single acoustic beacon. Several holes may be drilled at a single site by pulling the drill pipe above the seafloor (out of one hole), moving the ship some distance from the previous hole, and then drilling another hole.

For all ODP drill sites, a letter suffix distinguishes each hole drilled at the same site. For example: the first hole takes the site number and suffix $A$, the second hole takes the site number and suffix $B$, and so forth. This procedure is different from that used by DSDP (Sites 1 through 624 ) but prevents ambiguity between site- and hole-number designations.

The cored interval is measured in meters below the seafloor. The depth interval of an individual core is the depth below the seafloor that the coring operation began to the depth that the coring operation ended. Coring intervals are determined by the maximum length of a core barrel, $9.7 \mathrm{~m}$. The cored intervals, however, may be shorter and may not necessarily be adjacent to each other but may be separated by drilled intervals. In soft sediment, the drill string can be "washed ahead" with the core barrel in place but not recovering sediment by pumping water down the pipe at high pressure to wash the sediment out of the way of the bit and up the space between the drill pipe and wall of the hole. If thin, hard-rock layers are present, however, sampling of these resistant layers within the washed interval can be spotty.

Cores taken from a hole are numbered serially from the top of the hole downward. Maximum full recovery for a single core is $9.7 \mathrm{~m}$ of sediment or rock in a plastic liner $(6.6-\mathrm{cm}$ internal diameter), plus about a $0.2-\mathrm{m}$-long sample (without a plastic liner) in a core catcher. The core catcher is a device at the bottom of the core barrel that prevents the core from sliding out when the barrel is being retrieved from the hole. The sediment core, which is in the plastic liner, is then cut into 1.5 -m-long sections that are numbered serially from the top of the sediment core (Fig. 1); the routine for handling hard rocks is described in the "Basement Rocks" section (this chapter). When full recovery is obtained, the sections are numbered from 1 through 7 , the last section being shorter than $1.5 \mathrm{~m}$. For sediments and sedimentary rocks, the core-catcher sample is placed below the last section and treated as a separate section. For igneous and metamorphic rocks, material recovered in the core catcher is included at the bottom of the last section.
When recovery is less than $100 \%$, whether or not the recovered material is contiguous, the recovered sediment is placed at the top of the cored interval, and then 1.5-m-long sections are numbered serially, starting with Section 1 at the top. As many sections as needed are created to accommodate the length of the core recovered (Fig. 1); for example, $3 \mathrm{~m}$ of core sample in a plastic liner will be divided into two 1.5 -m-long sections. Sections are cut starting at the top of the recovered sediment, and the last section may be shorter than the normal 1.5 -m length. If, after the core has been split, fragments that are separated by a void appear to have been contiguous in situ, a note is made in the description of the section.

Samples are designated by distances in centimeters from the top of each section to the top and bottom of the sample interval in that section. A full identification number for a sample consists of the following information: (1) leg, (2) site, (3) hole, (4) core number and type, (5) section, and (6) interval in centimeters. For example, the sample-identification number " 105 647A-2R-2, 98-100 cm" means that a sample was taken between 98 and $100 \mathrm{~cm}$ from the top of Section 2 of rotary-drilled Core 2 , from the first hole drilled at Site 647 during Leg 105. A sample from the core catcher of this core might be designated " 105 647A-2R, CC (8-9 cm)."

All ODP core and sample identifiers indicate core type. The following abbreviations are used: $\mathrm{R}=$ rotary barrel; $\mathrm{H}=$ hydraulic piston core (HPC); $\mathrm{P}=$ pressure core barrel; $\mathrm{X}=$ extended core barrel $(\mathrm{XCB}) ; \mathrm{B}=$ drill-bit recovery; $\mathrm{C}=$ center-bit recovery; $\mathrm{I}=$ in-situ water sample; $\mathrm{S}=$ sidewall sample; $\mathrm{W}=$ wash-core recovery; $\mathrm{N}=$ navidrill core; and $\mathrm{M}=$ miscellaneous material. Only HPC, XCB, rotary, and wash cores were drilled on ODP Leg 105.

\section{Core Handling}

As soon as a core was retrieved on deck during Leg 105, a sample was taken from the core catcher and given to the paleontological laboratory for an initial age assessment.

The core was then placed on the long horizontal rack, and gas samples were taken by piercing the core liner and withdrawing gas into a vacuum-tube sampler. Voids within the core were sought as sites for gas sampling. Some of the gas samples were stored for shore-based study, but others were analyzed immediately as part of the shipboard safety and pollution-prevention program. Next, the core was marked into section lengths, each section was labeled, and the core was cut into sections. Interstitial-water (IW), organic geochemistry (OG), and physical-properties (PP) whole-round samples were then taken. Each section was sealed at the top and bottom by gluing on color-coded plastic caps, blue to identify the top of a section and clear for the bottom. A yellow cap was placed on section ends from which an IW whole-round sample had been removed. Similarly, red caps were placed on section ends from which an OG sample had been taken. The caps were usually attached to the liner by coating the end of the liner and the inside rim of the cap with acetone, and then the caps were taped to the liners.

Then the cores were carried into the laboratory, where the sections were again labeled, using an engraver to mark the full designation of the section. The length of core in each section and the core-catcher sample were measured to the nearest centimeter; this information was logged into the shipboard core-log data-base program.

The cores were then allowed to warm to room temperature (approximately $4 \mathrm{hrs}$ ) before they were split. During this time, the whole-round sections were run through the GRAPE device for estimating bulk density and porosity (see following text; Boyce, 1976) and the pass-through cryogenic magnetometer (see following text). After the core temperatures had equilibrated, thermal-conductivity measurements were made immediately before the cores were split. 


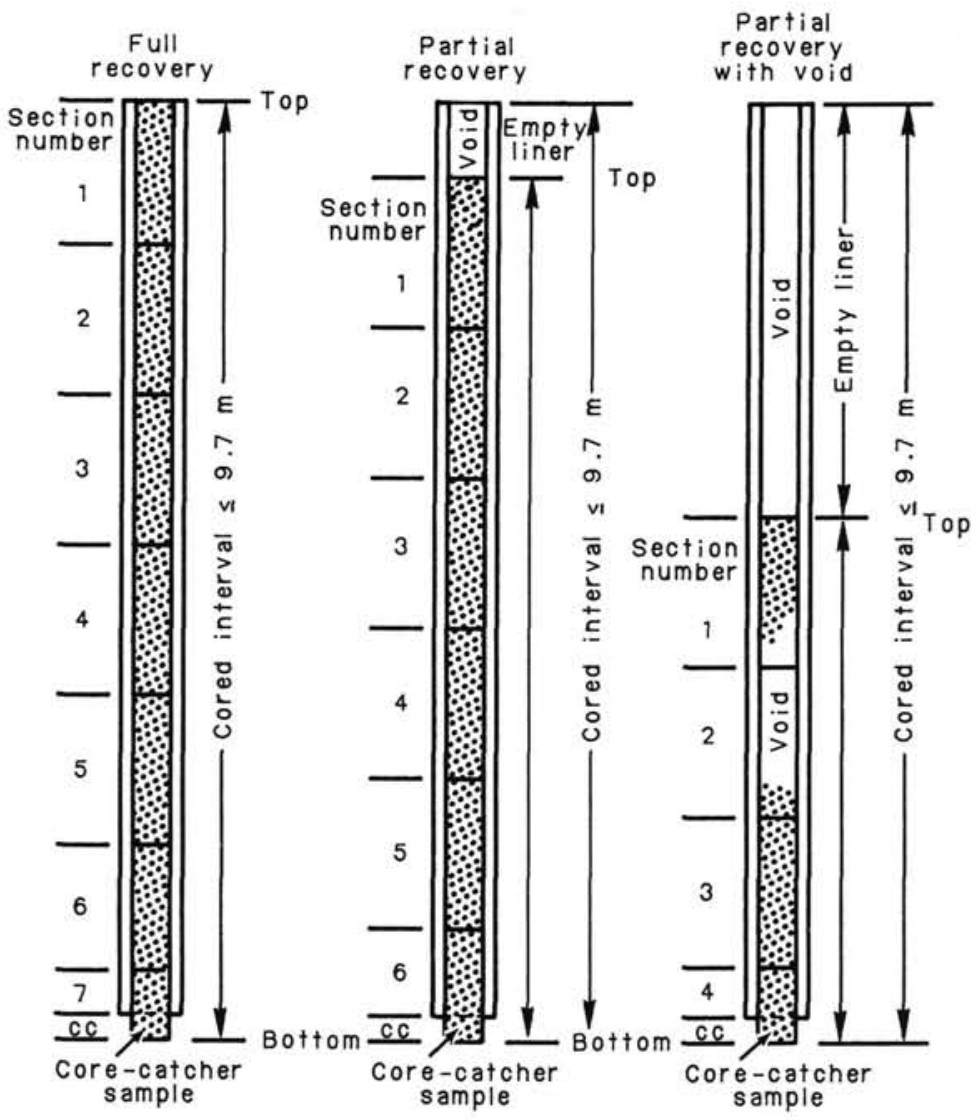

Figure 1. Diagram showing procedure for cutting and labeling core sections.

Cores of relatively soft material were split lengthwise into working and archive halves. The softer cores were split with a wire or saw, depending on the degree of induration. Harder cores were split with a band saw or diamond saw. As cores on Leg 105 were split with wire from the top to bottom, younger material could possibly have been transported down the core on the split face of each section. One should, thus, be aware that the very near-surface part of the split core could be contaminated.

The working half was sampled for both shipboard and shorebased laboratory studies. Each extracted sample was logged by the location and the name of the investigator receiving the sample in the sampling computer program. Records of all removed samples are kept by the curator at ODP. The extracted samples were sealed in plastic vials or bags and labeled. Samples were routinely taken for shipboard analysis of sonic velocity by the Hamilton Frame method, for water content by gravimetric analysis, for percentage of calcium carbonate present (carbonate bomb), and for other purposes. Many of these data are reported in the site chapters.

The archive half was described visually. Smear slides were made from samples taken from the archive half and were supplemented by thin sections taken from the working half. The archive half was then photographed with both black-and-white and color film, a whole core at a time.

Both halves were then put into labeled plastic tubes, sealed, and transferred to cold-storage space aboard the drilling vessel. Leg 105 cores were transferred from the ship by refrigerated vans to cold storage at the East Coast Repository at LamontDoherty Geological Observatory, Palisades, New York.

\section{CORE-DESCRIPTION FORMS ("BARREL SHEETS")}

The core-description forms (Fig. 2), or "barrel sheets," summarize the data obtained during shipboard analysis of each core. The following discussion explains the ODP conventions used in compiling each part of the core-description forms and the exceptions to these procedures adopted by Leg 105 scientists.

\section{Core Designation}

Cores are designated using site, hole, and core number and type as previously discussed (see "Numbering of Sites, Holes, Cores, and Samples" section, this chapter). In addition, the cored interval is specified in terms of meters below sea level (mbsl) and meters below seafloor (mbsf). On Leg 105, these depths were based on the drill-pipe measurement, as reported by the SEDCO coring technician and the ODP operations superintendent.

\section{Age Data}

Microfossil abundance, preservation, and zone assignment, as determined by the shipboard paleontologists, appear on the core-description form under the heading "Biostratigraphy Zone/ Fossil Character." The geologic age determined from the paleontological results appears in the "Time-Rock Unit" column.

On Leg 105, planktonic foraminifers, calcareous nannofossils, and dinocysts provided most of the age determinations, although radiolarians, diatoms, and benthic foraminifers were also useful age markers. Detailed information on the zonations and 


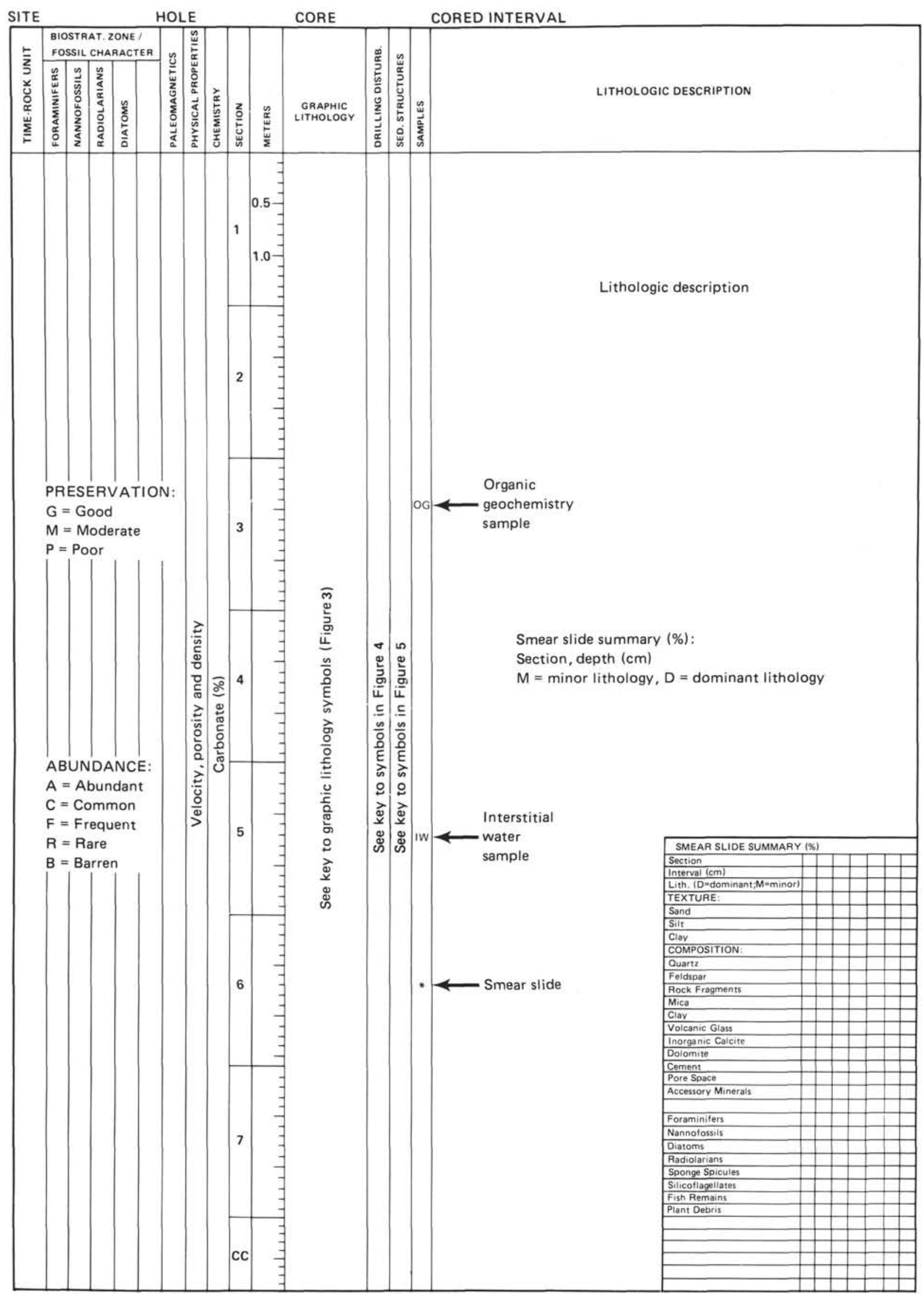

Figure 2. Sample form for describing sediments and sedimentary rocks cored ("barrel sheets"). 
terms used to report abundance and preservation appear in the "Biostratigraphy" section (this chapter).

\section{Paleomagnetic, Physical-Property, and Chemical Data}

Columns are provided on the core-description form to record paleomagnetic results, location of physical-properties samples (density, porosity, velocity, and thermal conductivity), and chemical data (percentage of $\mathrm{CaCO}_{3}$ determined using the carbonate bomb). Additional information on shipboard procedures for collecting these types of data appears in the "Paleomagnetics," "Physical Properties," and "Inorganic Geochemistry" sections (this chapter).

\section{Graphic Lithology Column}

The lithological-classification scheme presented here is represented graphically on the core-description forms using the symbols illustrated in Figure 3. Modifications and additions made to the graphic-lithology-representation scheme recommended by the JOIDES Sedimentary Petrology and Physical Properties Panel are discussed in the "Lithostratigraphy" section (this chapter).

\section{Sediment Disturbance}

The coring technique, which uses a 25 -cm-diameter bit having a 6-cm-diameter core opening, may result in extreme disturbance of the recovered core material. This is illustrated in the "Drilling Disturbance" column on the core-description form using the symbols in Figure 4, as described in the following disturbance categories that are recognized for soft and firm sediments:

1. Slightly deformed: bedding contacts are slightly bent.

2. Moderately deformed: bedding contacts have undergone extreme bowing.

3. Highly deformed: bedding is completely disturbed, sometimes showing symmetrical diapirlike structure.

4. Soupy: intervals are water saturated and have lost all aspects of original bedding.

The following categories are used to describe the degree of fracturing in hard sediments and igneous and metamorphic rocks (Fig. 4):

1. Slightly fractured: core pieces are in place and have very little drilling slurry or breccia.

2. Moderately fragmented: core pieces are in place or partly displaced, but original orientation is preserved or recognizable. Drilling slurry may surround fragments.

3. Highly fragmented: pieces are from the interval cored and probably in correct stratigraphic sequence (although they may not represent the entire section), but original orientation is totally lost.

4. Drilling breccia: core pieces have completely lost their original orientation and stratigraphic position and may be completely mixed with drilling slurry.

\section{Sedimentary Structures}

In the soft and even in some harder sedimentary cores, distinguishing between natural structures and those created by the coring process may be extremely difficult. However, where such structures were observed, they are indicated on the "Sedimentary Structure" column of the core-description forms. A key to the structural symbols used on Leg 105 is given in Figure 5.

\section{Samples}

The position of samples taken from each core for shipboard analysis is indicated in the "Samples" column in the core-de- scription form. An asterisk $\left({ }^{*}\right)$ indicates the location of smear slide samples. The symbols $I W, O G$, and $P P$ designate wholeround interstitial-water, frozen organic geochemistry, and physical-properties samples, respectively.

Although not indicated in the "Samples" column, the position of samples for routine physical-property and carbonatebomb analyses are indicated by a square in the "Physical Properties" and "Chemistry" columns (these samples are taken from the working half of the core and generally, although not always, correspond to smear slide locations in the archive half).

Shipboard paleontologists generally base their age determinations on core-catcher samples, although additional samples from other parts of the core may be examined when required.

\section{Lithologic Description-Text}

The lithologic description that appears on each core-description form consists of two parts: (1) a brief summary of the major lithologies observed in a given core in order of importance, followed by a description of sedimentary structures and features, and (2) a description of minor lithologies observed in the core, including data on color, occurrence in the core, and significant features.

\section{Smear Slide Summary}

A table summarizing smear slide and thin-section data, if available, appears on each core-description form. The section and interval from which the sample was taken are noted, as well as identification as a dominant $(D)$ or minor $(M)$ lithology in the core. The percentage of all identified components (totaling $100 \%$ ) is listed. As explained in the following text, this data is used to classify the recovered material.

\section{SEDIMENT CLASSIFICATION}

Leg 105 shipboard scientists chose to modify the sediment classifications originally recommended by the JOIDES Sedimentary Petrology and Physical Properties Panel (SP4 classification in Ross, Neprochnov, et al., 1978). The relatively few categories offered by the "pelagic biogenic" and "terrigenous" SP4 classifications were insufficient for the wide variety of hemipelagic sediments encountered at the Leg 105 sites. Following the rationale of the DSDP Leg 84 shipboard party (Baltuck et al., 1985 ) and Dean et al. (1985), we more finely subdivided certain categories to provide better resolution for determining sediment facies. As in all sediment classifications, however, the divisions between certain categories are somewhat arbitrary.

Unlike the SP4 classification, the scheme presented here is internally consistent and descriptive rather than genetic. Composition and/or texture are the only criteria used to define the sediment classes. Textural criteria are most important for terrigenous sediments, whereas composition becomes more significant in categorizing pelagic sediments.

The classifications are designed for marine sediment data originating principally from shipboard visual estimates of smear slides using a petrographic microscope. They are estimates of component and size abundance on the slide and may differ somewhat from more accurate analyses of grain size, carbonate content, and mineralogy. From past experience, quantitative estimates of distinctive minor components are accurate to within $1 \%-2 \%$, but for major constituents accuracy is only $\pm 10 \%$.

\section{Nonbiogenic-Clastic Sediments (Terrigenous)}

The nonbiogenic-clastic category includes sediments having $>75 \%$ nonbiogenic components. In this major category, nonbiogenic-clastic sediments are subdivided into textural groups on the basis of the relative proportions of sand, silt, and clay. The textural classification follows the triangular diagram shown in Figure 3. A single-component sediment class (i.e., end mem- 


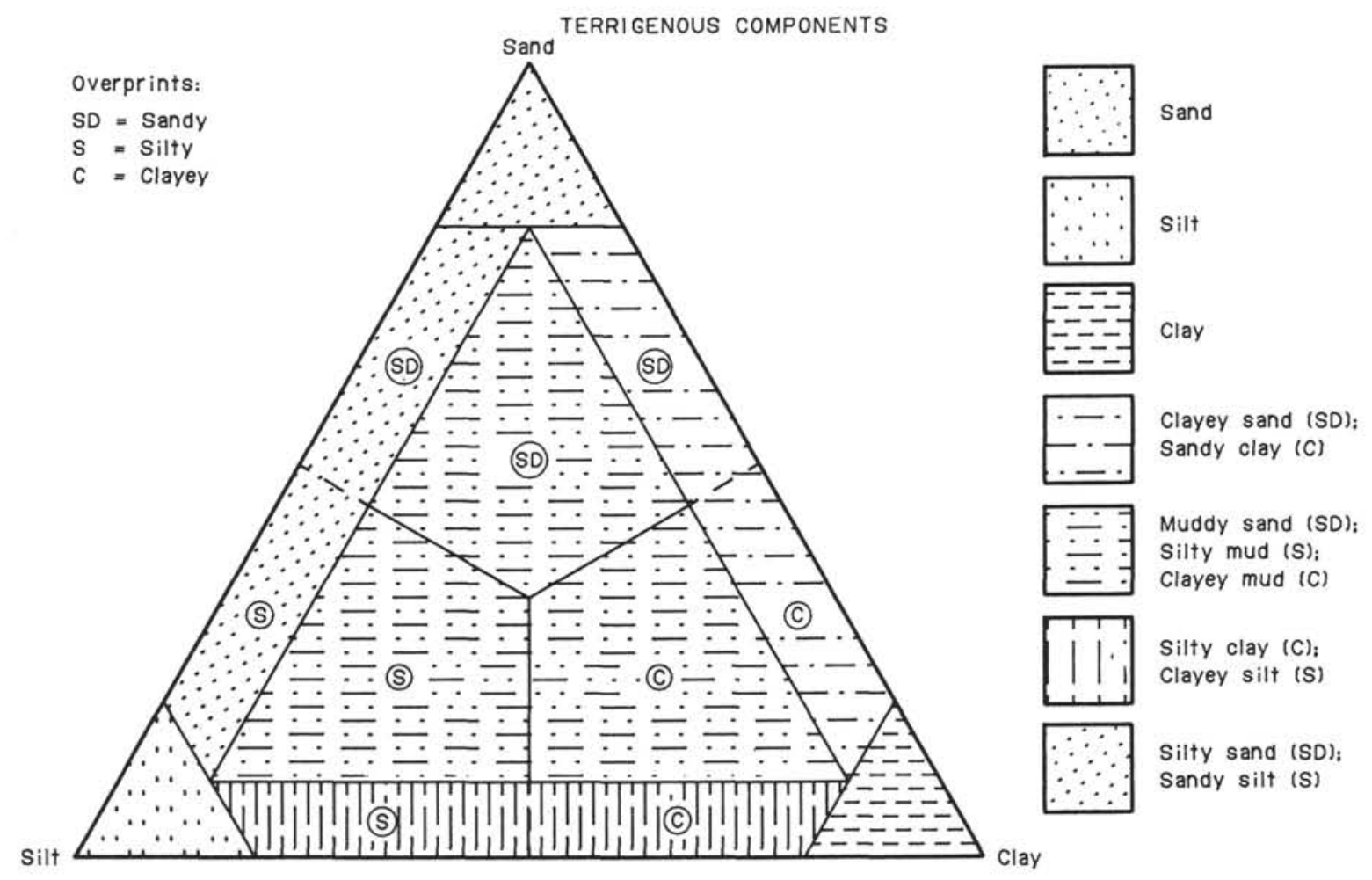

BIOGENIC COMPONENTS

(not strictly sediment/rock types)

\section{A. Carbonates}
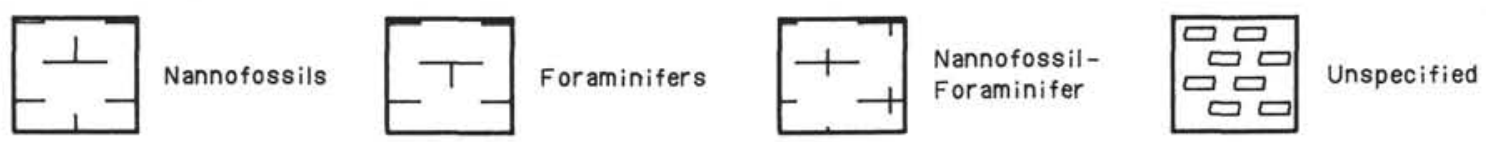

B. Silica
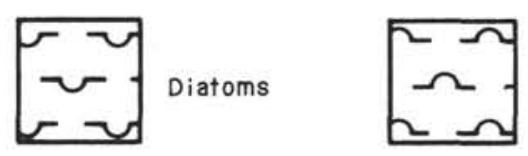

Radiolar ians

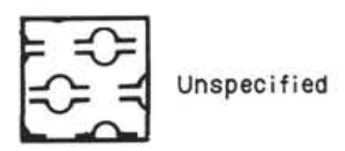

Special symbols

(G) Glauconitic

(P) Pyrite

Figure 3. Lithologic classification and symbols used during Leg 105. These symbols are shown in the "Graphic Lithology" column of the core-description form.

bers such as sand, silt, or clay) occurs where the dominant component exceeds $80 \%$.

In simple two-component mixtures (i.e., where the third component is $<10 \%$ ), the sediment receives the name of the dominant component, modified by the secondary component (e.g., where clay $=40 \%$ and silt $=60 \%$, the sediment is designated a "clayey silt").

Our classification scheme differs from the scheme of Folk (1980) that was recommended by Dean et al. (1985). Instead, we provide a uniform and symmetrical division of fields but still ask the petrographer to estimate whether the relative proportion of any component is $>10 \%$ or $>80 \%$.
We retained the terms "mud" and "muddy" but apply them to mixtures of sand, silt, and clay where no one component is $>10 \%$. Within the "mud" category, the sediment name depends on the dominant component, so that sand-, silt-, and clay-rich muds are called, respectively, muddy sands, silty muds, and clayey muds.

The scheme for the nonbiogenic-clastic sediments (Fig. 3) is modified where a fourth component is present. The term gravel applies to sediment in which $>80 \%$ of the clasts are coarser than sand (Fig. 6). If gravel constitutes $50 \%-80 \%$ of the sediment, gravel is modified by such terms as "muddy," "sandy," and "calcareous." If gravel forms $50 \%-25 \%$, the sediment name 


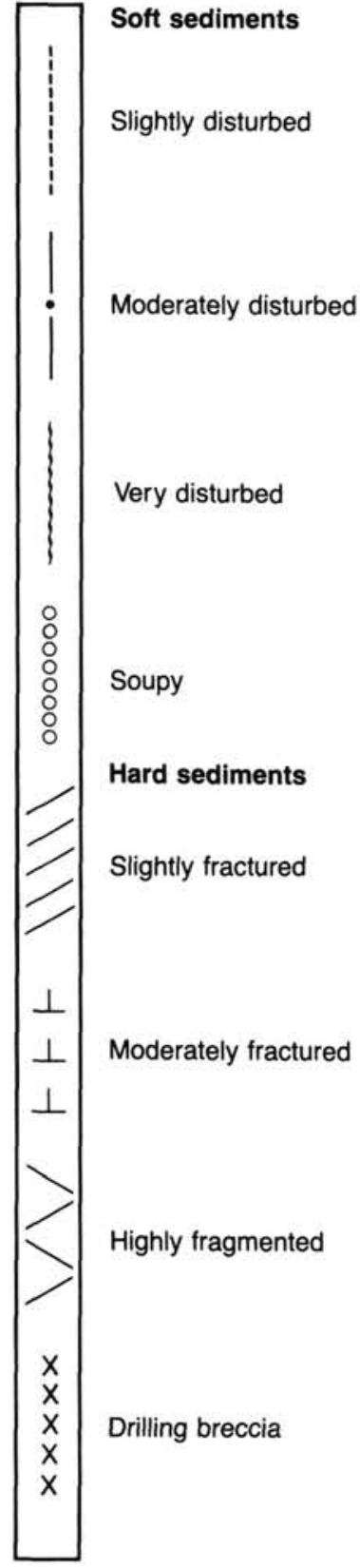

Figure 4. Standard symbols for drilling disturbance that are shown in the core-description forms.

is modified by the term "gravelly." If $10 \%-25 \%$ is gravel, the sediment name is modified by "gravel-bearing." Isolated gravelsized clasts $(<10 \%)$ do not affect the sediment name but are noted separately.

Similarly, if total biogenic components exceed $10 \%$ but are $<25 \%$, then the appropriate names should be used as modifiers (e.g., if calcareous nannofossils $=12 \%$, clay $=40 \%$, and silt $=$ $48 \%$, the sediment is designated a "nannofossil-bearing clayey silt"; or if calcareous nannofossils $=6 \%$, siliceous diatoms $=$ $8 \%$, clay $=38 \%$, and silt $=48 \%$, the appropriate sediment name is "nannofossil- and diatom-bearing clayey silt"). The modifier closest to the actual major sediment name is, by convention, the most abundant minor component, and the least abundant component appears first. At Leg 105 sites, many sediments consist of extrabasinal, terrigenous carbonate detritus. In this instance, we employed the term "detricarbonate" as a com-

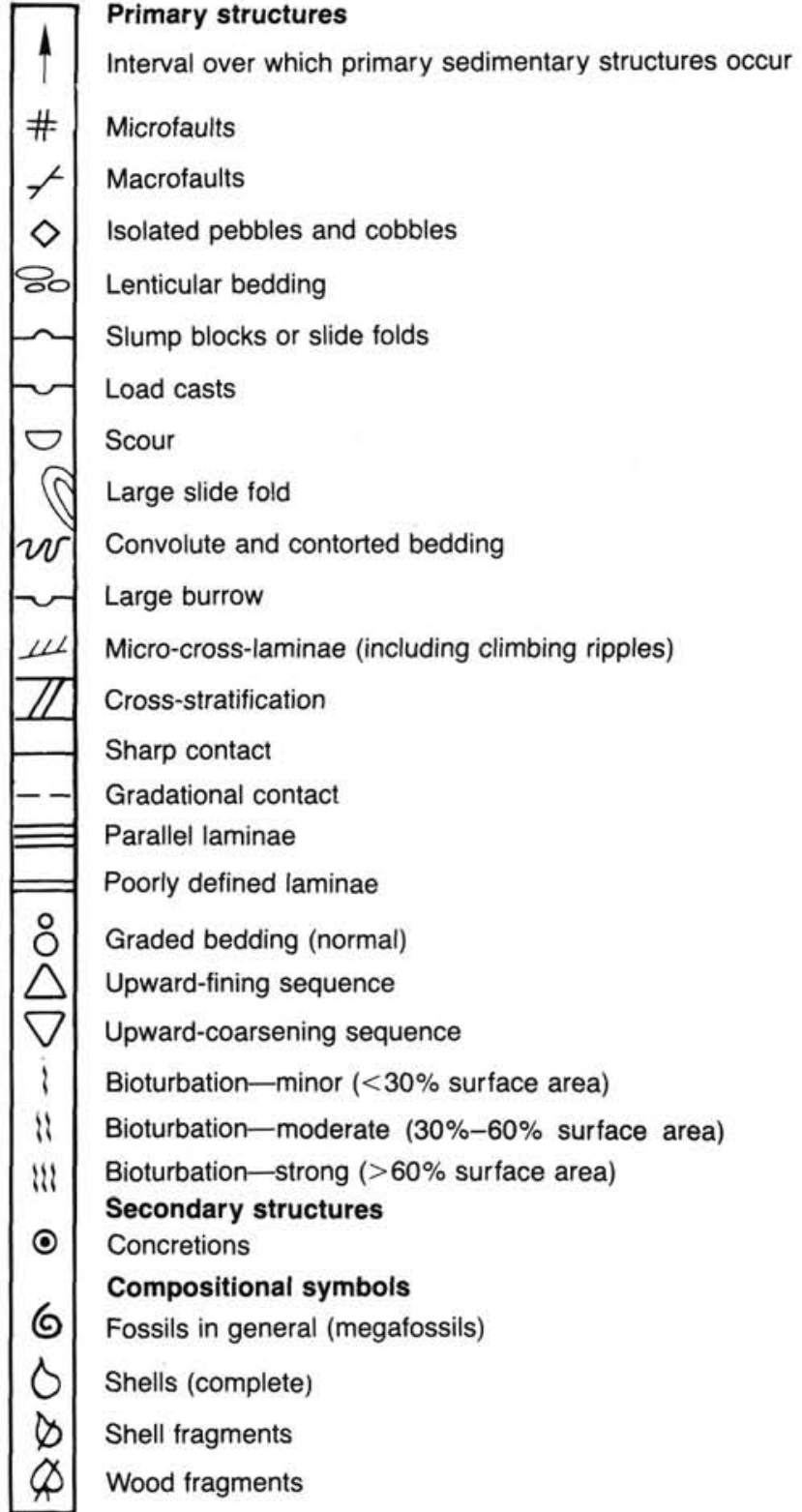

Figure 5. Standard symbols for sedimentary structures recognized in sediments recovered during Leg 105 . These symbols are shown in the "Sedimentary Structure" column of the core-description form.

positional modifier where detrital carbonate content exceeds $20 \%$ (e.g., detricarbonate silty mud).

On Leg 105, many sediments contained significant amounts of sand, the most difficult component to estimate using smear slides. When sediments were unconsolidated, a rapid-settling technique was used to ascertain better the volumetric proportion of sand-sized particles. Although probably only accurate to about $\pm 10 \%$ of the amount present, this technique proved satisfactory and gave reproducible results. The method is as follows:

1. Put about $1 \mathrm{~cm}^{3}$ of sediment in a $15-\mathrm{cm}^{3}$ Nalgene centifuge tube.

2. Add $2 \mathrm{~mL}$ of $5 \%$ Calgon solution, using an automatic dispensor to ensure accurate delivery. Read the total volume, and obtain the original sediment volume by difference.

3. Bring the volume to $10 \mathrm{~mL}$ with distilled water from a wash bottle. 

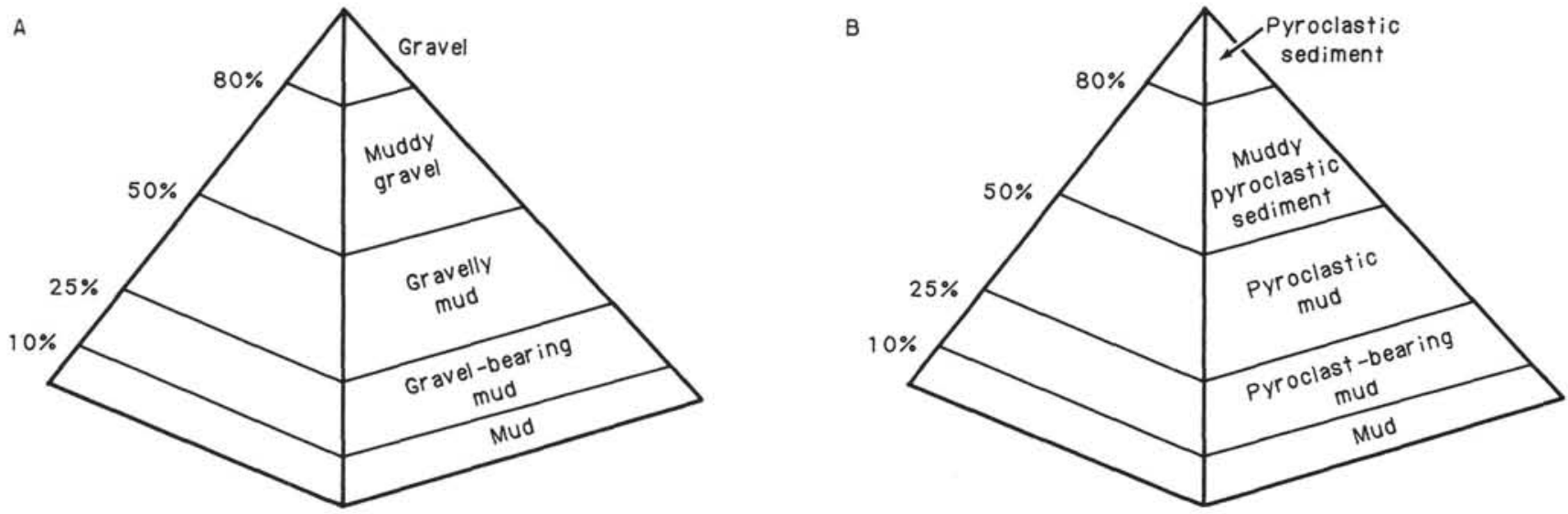

Figure 6. A. Classification scheme in which fourth component is gravel. Base of tetrahedron $A$ is the classification scheme for nonbiogenic-clastic sediments (from Fig. 6). Modifiers are applied to the general terrigeneous name "mud," for which other names can be substituted. B. Classification scheme in which fourth component is pyroclastic sediment. Base of tetrahedron is either the terrigeneous or the biogenic classification scheme (from Fig. 6 or Fig. 7). As in $A$, the general term "mud" may be replaced by other sediment names.

4. Shake vigorously, stand upright, and read sand content (in volume) after $25 \mathrm{~s}$. Calculate sand volume as a percentage of the total sediment volume.

This method does not give satisfactory results for silt or clay because of flocculation at the high concentration levels used and because of the several hour wait for the finer fractions to settle. The relative proportions of silt and clay were determined from smear slides.

\section{Biogenic Sediments}

If the percentage of biogenic components exceeds $25 \%$, the classification shown in Figure 3 is no longer applicable, and the scheme shown in Figure 7 and discussed as follows should be used.

We employed a biogenic-nonbiogenic classification boundary similar to that suggested by Dean et al. (1985), who stated that if the total of biogenic components (siliceous plus carbonate) is $>50 \%$, the main name is ooze, modified by the name(s) of the dominant biogenic component(s). It should be understood that in this discussion of biogenic sediments, the terms "siliceous" and "carbonate" refer to biogenic sediments. We prefer "biocarbonate" to "carbonate" as a sediment modifier to avoid confusion with the scheme for terrigenous sediments, in which carbonate may be entirely detrital.

If the total nonbiogenic component is between $50 \%$ and $75 \%$, we termed the sediment a mud (with appropriate modifier). The user should note that the term mud represents nonbiogenic clastic sediments of all types. Sand, silt, and clay (with or without modifiers) may be substituted for mud.

When $25 \%-50 \%$ of an ooze consists of nonbiogenic components, the terms "clayey," "sandy," "silty," and "muddy" are used as modifiers. When $10 \%-25 \%$ of an ooze consists of nonbiogenic components, the terms "clay-," "sand-," "silt-," and "mud-bearing" are used as modifiers.

To distinguish between categories of biogenic ooze, we employ a simple set of ratios $(4: 1,1: 1,1: 4)$ and their appropriate modifiers. The resulting four major categories of ooze are biocarbonate ooze, siliceous biocarbonate ooze, biocarbonate siliceous ooze, and siliceous ooze. This terminology holds throughout the ooze category and continues as modifying terms into the nonbiogenic part of the scheme. The terms "biocarbonate" and "biosiliceous" represent all types of biogenic constituents; more specific modifiers are usually substituted, such as "nannofossil," "diatomaceous," etc.
Where applicable, one or several modifiers may be used in naming the sediment encountered. The dominant component always appears last in the name, preceded by minor components; the least common constituent is listed first. Where two components constitute a biogenic category, the modifier may be hyphenated. For example, a sediment containing $20 \%$ clay, $30 \%$ diatoms, $22 \%$ foraminifers, and $28 \%$ nannofossils would fall into the "clay-bearing siliceous biocarbonate ooze" category. Its name, however, would be clay-bearing diatomaceous foraminifer-nannofossil ooze. The term "ooze" may be replaced by other terms indicating different degrees of induration (see following text). A difficulty with our scheme is that the term "carbonate mud" is commonly used by carbonate petrologists for a pure calcite/aragonite sediment with clay- and silt-sized grains, whereas we use the term "biocarbonate mud" for a siliclastic (or at least terrigenous) mud with biogenic carbonate components. Usually, however, fossil names (e.g., foraminifer-nannofossil mud) are preferred and confusion is avoided. If the adjective "biocarbonate" is restricted to our scheme, then confusion should not arise among carbonate petrologists.

\section{Other Sediments (including "Pelagic Clay")}

In keeping with the classification scheme presented here and in concurrence with the suggestions of Dean et al. (1985), zeolite minerals, organic carbon, ferromanganese oxides, and generally other authigenic components are used as sediment modifiers. Because these are generally minor components, however, we chose to apply the term "-bearing" for abundances less than $10 \%$ where deemed important (e.g., "zeolite-bearing mud," "siderite-bearing siliceous ooze"). Where these components compose more than $10 \%$ of the sediment, terms such as "zeolitic," "glauconitic," "ferromanganese" may be used as the initial modifier. For particular studies, these terms should be defined as precisely as possible.

\section{Induration}

We recognize three classes of induration, or lithification, for biogenic sediments and two classes for nonbiogenic sediments. For biogenic sediments and sedimentary rocks, the following categories (after Gealy et al., 1971) are used:

1. Soft: ooze; has little strength and is readily deformed under pressure of finger or broad blade of spatula.

2. Firm: chalk, diatomite, radiolarite; partly lithified and readily scratched with fingernail or edge of spatula. 


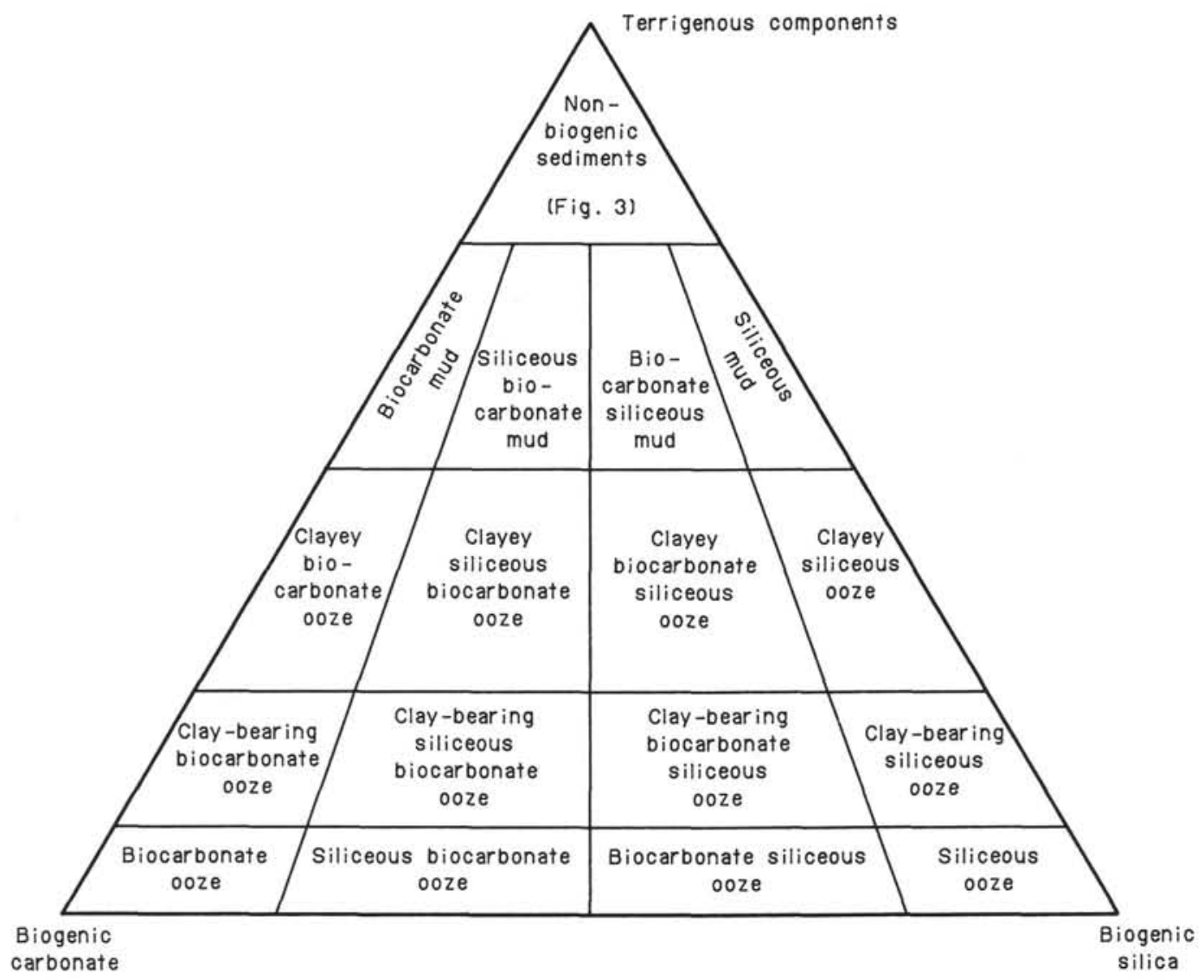

Figure 7. Compositional classification for biogenic marine sediments having a nonbiogenic third component.

3. Hard: limestone, porcellanite, chert; well lithified and cemented, resistant or impossible to scratch with fingernail or edge of spatula.

For nonbiogenic-clastic sediments, the two classes of induration are as follows:

1. Soft: sand, silt, clay, mud; sediment core can be split with wire cutter.

2. Hard: sandstone, siltstone; cannot be compressed with finger pressure, or core must be cut with band saw or diamond saw.

\section{Pyroclastic Sediments}

To describe volcanogenic material, we follow the recommendations of Dean et al. (1985) and the scheme used in DSDP Leg 81 (Roberts et al., 1984). The main criteria used in these classifications are grain size, degree of consolidation, fragmental composition, and degree of dilution by nonpyroclastic components.

Pyroclasts having mean diameters $>64 \mathrm{~mm}$ are termed "blocks" or "bombs," those between 2 and $64 \mathrm{~mm}$ are "lapilli," and those $<2 \mathrm{~mm}$ are "ash particles." Unconsolidated pyroclastic sediments are termed bomb or block tephras, lapilli tephras, or ashes, depending on the grain size as defined previously. The equivalent consolidated rocks are termed agglomerates or pyroclastic breccias, lapilli tuffs, or tuffs.

The pyroclastic terms, tephra, ash, tuff, and agglomerate, apply to sediment and rock with $>80 \%$ pyroclastic components (Fig. 6). If the pyroclastic content falls between $50 \%$ and $80 \%$, the sediment names are modified by such terms as "muddy," "sandy," "biocarbonate," and "diatomaceous." If the pyro- clasts form $<50 \%$, the sediment name is modified by terms such as "ashy" or "tuffaceous." If from $10 \%$ to $25 \%$ pyroclastic debris is present, the sediment name is modified by terms such as "ash-bearing" and "lapilli-bearing."

Note that these names apply to sediments containing volcanic ejecta that are essentially not reworked. If terrigenous particles are derived from volcanic source rocks or if the ejecta have been sorted and redeposited by marine processes, then the sediments are volcaniclastic, not pyroclastic, and the scheme for nonbiogenic-clastic sediments should be employed. The term "volcaniclastic" can, of course, be included as a sediment modifier (e.g., "volcaniclastic muddy sand"), as are the terms "glauconitic" and "zeolitic."

\section{BIOSTRATIGRAPHY}

Leg 105 allowed a unique opportunity to examine high-latitude microfossil faunas and floras and to compare these with the faunas and floras of the middle and low latitudes. The Leg 105 paleontologists established a biostratigraphic framework for use during the cruise (Figs. 8 and 9). Both low-latitude microfossil zonations as well as zonal schemes established for the Norwegian-Greenland Sea and the high-latitude North Pacific are incorporated into this biostratigraphic framework. This framework is established only as a reference point to allow comparisons between the observed species and their stratigraphic ranges with a known chronostratigraphy. This framework serves as an explicitly stated starting point in the iterative process of working toward a chronostratigraphy of Baffin Bay and the Labrador Sea.

The correlations of biostratigraphic zonations with the geomagnetic polarity time scale follows that of Berggren et al. 


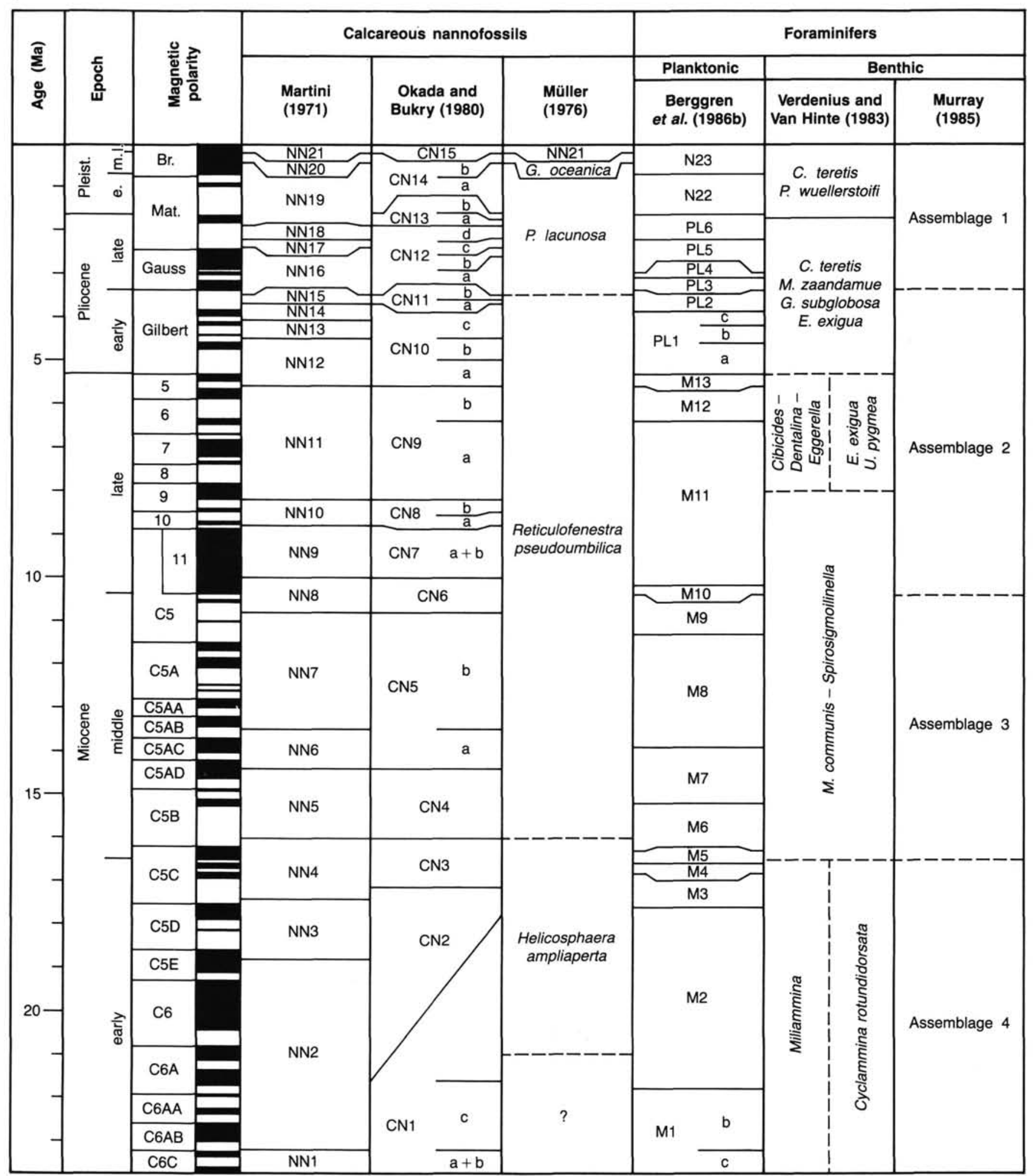

Figure 8. Correlation of the microfossil zones and datums to the Neogene chronostratigraphy of Berggren et al. (1986a and b).

(1986a and b) and is used here as the chronostratigraphic framework for Leg 105 studies (Figs. 8 and 9). We adhere to the most recent version of this chronostratigraphy by using an anomaly 5-Chron 11 correlation rather than the previously accepted anomaly 5-Chron 9 correlation. This more recent correlation results in generally younger absolute ages for late middle and early late
Miocene (13.6-6.6 m.y.) microfossil datums and zones. The epoch/stage boundaries used for Leg 105 studies are as follows:

$\begin{array}{ll}\text { Pliocene/Pleistocene boundary } & 1.6 \mathrm{Ma} \\ \text { early/late Pliocene boundary } & 3.4 \mathrm{Ma} \\ \text { Miocene/Pliocene boundary } & 5.3 \mathrm{Ma}\end{array}$




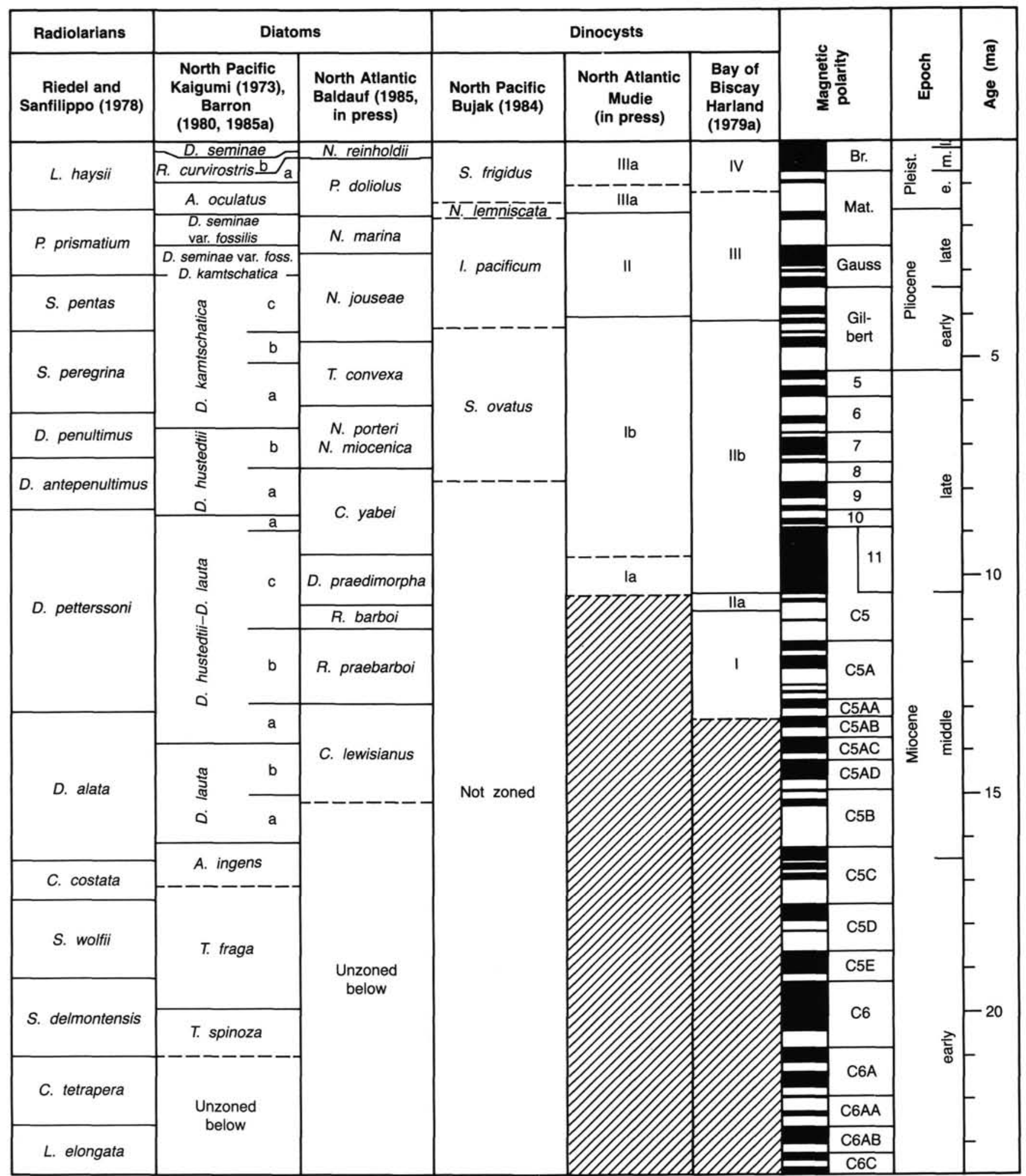

Figure 8 (continued).

middle/late Miocene boundary early/late Miocene boundary Oligocene/Miocene boundary early/late Oligocene boundary Eocene/Oligocene boundary middle/late Eocene boundary
$10.4 \mathrm{Ma}$

$16.5 \mathrm{Ma}$

$23.7 \mathrm{Ma}$

$30.0 \mathrm{Ma}$

$36.6 \mathrm{Ma}$ $40.0 \mathrm{Ma}$ early/middle Eocene boundary $52.0 \mathrm{Ma}$

Paleocene/Eocene boundary $\quad 57.8 \mathrm{Ma}$

The age estimates of Berggren et al. (1986a and b) for the normal magnetic-polarity intervals are shown in Table 1 . The microfossil zones and their calibration to the chronostratigra- 


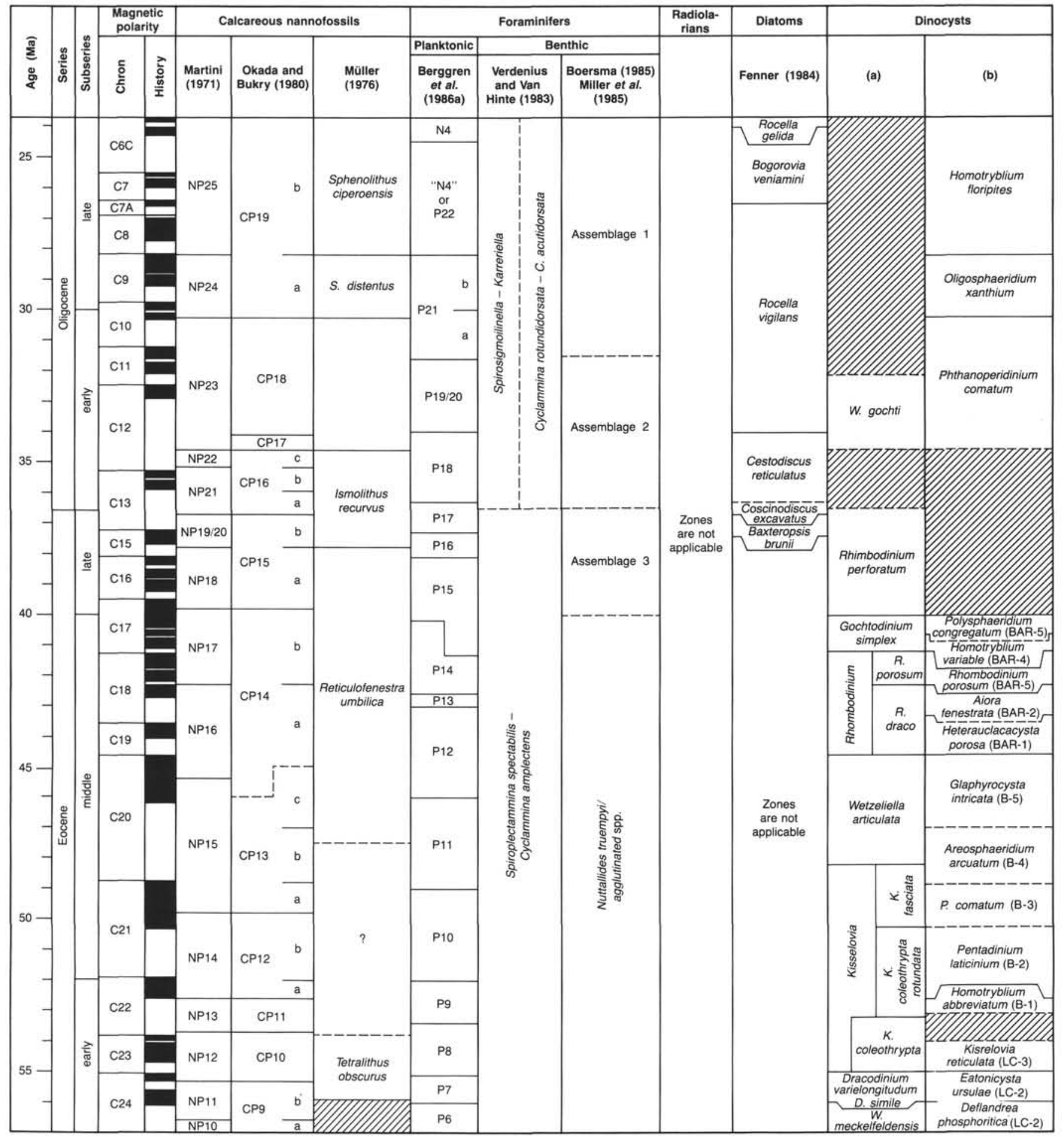

Figure 9. Correlation of the microfossil zones and datums to the Paleogene chronostratigraphy of Berggren et al. (1986a). A. Costa and Downie (1976), Châteauneuf and Gruas Cavagnelto (1978), Châteauneuf (1980), and Bujak (1979). B. Eaton (1976), Bujak et al. (1980), Benedek and Müller (1974).

phy of Berggren et al. (1986a and b) are discussed in following text.

\section{Calcareous Nannofossils}

On Leg 105, the calcareous nannofossil zonations of Martini (1971) and Okada and Bukry (1980) were used when possible as the basis for age determinations of sediments. These zonations, however, are made primarily according to the presence of spe- cies typical of the low-latitudes that may be sparse or absent in the high-latitudes. Müller (1976) modified Martini's (1971) zonation for use in the Norwegian-Greenland Sea region by combining zones defined by warm-water species (Fig. 8). Müller's zonation is used at Baffin Bay Site 645 .

Calibration of the calcareous nannofossil events (Martini, 1971; Okada and Bukry, 1980) to the polarity scale follows Berggren et al. (1986a and b). The marker species used by Mül- 
Table 1. Age estimates of the normal magnetic-polarity intervals in millions of years (from Berggren et al., 1986a and b).

\begin{tabular}{|c|c|c|c|}
\hline $\begin{array}{l}\text { Normal-polarity } \\
\text { interval (Ma) }\end{array}$ & Anomaly & $\begin{array}{c}\text { Normal-polarity } \\
\text { interval (Ma) }\end{array}$ & Anomaly \\
\hline $0.00-0.73$ & 1 & $24.04-24.21$ & $6 C$ \\
\hline $0.91-0.98$ & & $25.50-25.60$ & 7 \\
\hline $1.66-1.88$ & 2 & $25.67-25.97$ & 7 \\
\hline $2.47-2.92$ & $2 \mathrm{~A}$ & $26.38-26.56$ & $7 \mathrm{~A}$ \\
\hline $2.99-3.08$ & $2 \mathrm{~A}$ & $26.86-26.93$ & 8 \\
\hline $3.18-3.40$ & $2 \mathrm{~A}$ & $27.01-27.74$ & 8 \\
\hline $3.88-3.97$ & 3 & $28.15-28.74$ & 9 \\
\hline $4.10-4.24$ & 3 & $28.80-29.21$ & 9 \\
\hline $4.40-4.47$ & 3 & $29.73-30.03$ & 10 \\
\hline $4.57-4.77$ & 3 & $30.09-30.33$ & 10 \\
\hline $5.35-5.53$ & $3 \mathrm{~A}$ & $31.23-31.58$ & 11 \\
\hline $5.68-5.89$ & $3 \mathrm{~A}$ & $31.64-32.06$ & 11 \\
\hline $6.37-6.50$ & & $32.46-32.90$ & 12 \\
\hline $6.70-6.78$ & 4 & $35.29-35.47$ & 13 \\
\hline $6.85-7.28$ & 4 & $35.54-35.87$ & 13 \\
\hline $7.35-7.41$ & 4 & $37.24-37.46$ & 15 \\
\hline $7.90-8.21$ & $4 \mathrm{~A}$ & $37.48-37.68$ & 15 \\
\hline $8.41-8.50$ & $4 \mathrm{~A}$ & $38.10-38.34$ & 16 \\
\hline $8.71-8.80$ & & $38.50-38.79$ & 16 \\
\hline $8.92-10.42$ & 5 & $38.83-39.24$ & 16 \\
\hline $10.54-10.59$ & & $39.53-40.43$ & 17 \\
\hline $11.03-11.09$ & & $40.50-40.70$ & 17 \\
\hline $11.55-11.73$ & $5 \mathrm{~A}$ & $40.77-41.11$ & 17 \\
\hline $11.86-12.12$ & $5 \mathrm{~A}$ & $41.29-41.73$ & 18 \\
\hline $12.46-12.49$ & & $41.80-42.23$ & 18 \\
\hline $12.58-12.62$ & & $42.30-42.73$ & 18 \\
\hline $12.83-13.01$ & SAA & $43.60-44.06$ & 19 \\
\hline $13.20-13.46$ & $5 \mathrm{AB}$ & $44.66-46.17$ & 20 \\
\hline $13.69-14.08$ & $5 \mathrm{AC}$ & $48.75-50.34$ & 21 \\
\hline $14.20-14.66$ & $5 \mathrm{AD}$ & $51.95-52.62$ & 22 \\
\hline $14.87-14.96$ & $5 B$ & $53.88-54.03$ & 23 \\
\hline $15.13-15.27$ & $5 B$ & $54.09-54.70$ & 23 \\
\hline $16.22-16.52$ & $5 C$ & $55.14-55.37$ & 24 \\
\hline $16.56-16.73$ & $5 \mathrm{C}$ & $55.66-56.14$ & 24 \\
\hline $16.80-16.98$ & $5 \mathrm{C}$ & $58.64-59.24$ & 25 \\
\hline $17.57-17.90$ & 5D & $60.21-60.75$ & 26 \\
\hline $18.12-18.14$ & $5 \mathrm{D}$ & $63.03-63.54$ & 27 \\
\hline $18.56-19.09$ & $5 \mathrm{E}$ & $64.29-65.12$ & 28 \\
\hline $19.35-20.45$ & 6 & $65.50-66.17$ & 29 \\
\hline $20.88-21.16$ & $6 \mathrm{~A}$ & $66.74-68.42$ & 30 \\
\hline $21.38-21.71$ & $6 \mathrm{~A}$ & $68.52-69.40$ & 31 \\
\hline $21.90-22.06$ & $6 \mathrm{AA}$ & $71.37-71.65$ & 32 \\
\hline $22.25-22.35$ & $6 \mathrm{AA}$ & $71.91-73.55$ & 32 \\
\hline $22.57-22.97$ & $6 \mathrm{~B}$ & $73.96-74.01$ & \\
\hline $23.27-23.44$ & $6 C$ & $74.30-80.17$ & 33 \\
\hline $23.55-23.79$ & $6 \mathrm{C}$ & $84.00-118.00$ & 34 \\
\hline
\end{tabular}

ler (1976) are correlated to the Martini (1971) zonation and are, therefore, indirectly calibrated to the polarity scale.

\section{Planktonic Foraminifers}

Correlation of the planktonic foraminiferal datums and zones to the chronostratigraphy of Berggren et al. (1986a and b) and to the calcareous nannofossil zonation of Martini (1971) follows that of Berggren et al. (1986a and b). Foraminiferal "M" zones proposed by Berggren et al. (1983) and "PL" zones of Berggren $(1973,1977)$ are of limited use in Baffin Bay and Labrador Sea sediments primarily because these zonations are based on subtropical and temperate species. The polar and subpolar species that occur at Leg 105 sites are characterized by long stratigraphic ranges and are not biostratigraphically useful.

Secondary foraminiferal datums were used to assign "N" and " $\mathrm{P}$ " zones in previous studies from the Labrador and Norwegian-Greenland Seas (Berggren, 1972; Berggren and Schnitker, 1983), as well as from the Goban Spur region (Snyder and Waters, 1985). In high latitudes, some of the primary datums of Berggren et al. (1986a and b) exhibited diachroneity of $0.5-1.0$ $\mathrm{Ma}$, as indicated by first-order correlations with the magnetostratigraphy. Nevertheless, we used Berggren's primary datums because they are directly correlated to the nannofossil zones and to magnetostratigraphy. However, the first (FO) and last (LO) stratigraphic-appearance datums of several secondary marker species from the Labrador Sea and North Atlantic have also been used. In these instances, the lowest FO and highest LO were selected. These events may prove useful in low-diversity polar and subpolar faunas.

\section{Benthic Foraminifers}

Benthic foraminifers have limited usefulness for chronostratigraphy because silled basins tend to have endemic faunas and the distribution of these organisms is controlled largely by water-mass properties and other depth-related parameters. Within a basin, however, benthic foraminifers serve as a basis for many regional zonations.

We compiled Eocene to Holocene benthic foraminiferal assemblages from DSDP Legs 12, 38, 48, 80, and ODP Leg 104. Depending on the composition of assemblages recovered at Sites 645 and 646, either Norwegian-Greenland Sea or North Atlantic assemblage zones can be used for the Neogene and upper $\mathrm{Pa}$ leogene.

First-order correlations can be drawn between benthic foraminiferal datums and magnetobiostratigraphy at DSDP Site 516 in the South Atlantic (Berggren et al., 1983; Tjalsma, 1983), at Site 549 (Boersma, 1985; Miller et al., 1985; Townsend, 1985), and at Site 558 (Boersma, 1985) in the North Atlantic. Although no formal benthic zonation exists for the North Atlantic, a number of species have relatively isochronous first-appearance datums (FAD) and last-appearance datums (LAD) in deep-water sediments. Stratigraphic ranges of cosmopolitan deep-water calcareous benthic foraminifers were compiled by Van Morkhoven et al. (pers. comm., 1986). Stratigraphic ranges of taxa from the Labrador Sea sites can be compared with North Atlantic data for assigning ages to benthic foraminiferal assemblages in Sites 646 and 647 .

Agglutinated assemblages in Baffin Bay and in the Paleogene of Site 647 can be compared to zonations from the Norwegian-Greenland Sea (Verdenius and van Hinte, 1983), the North Sea (F. M. Gradstein, pers. comm., 1986), the Carpathian Mountains (Geroch and Nowak, 1984), and the Beaufort Sea (Young and McNeil, 1984). In these regions, however, the zonations have not been correlated with magnetostratigraphy.

\section{Diatoms}

Diatom biostratigraphic studies during Leg 105 adhere when possible to the Neogene zonations of Koizumi (1973; modified by Barron, 1980, 1985a) and Baldauf (1985, in press). The zonation of Koizumi (1973) that was later refined by Barron (1980, 1985a) was defined for use in the middle- and high-latitude North Pacific Ocean. However, recent biostratigraphic studies have shown this zonation to be applicable both in the Norwegian-Greenland Sea (Dzinoridze et al., 1978) and in the highlatitude North Atlantic Ocean (Baldauf, 1985). Correlations of the Neogene diatom datums to the magnetostratigraphic record are based on the studies of Barron et al. (in press) and Baldauf (1985, in press).

Both Schrader and Fenner (1976) and Dzinoridze et al. (1978) proposed a Paleogene diatom zonation for use in the Norwegian-Greenland Sea. These zonations are partly recognized in sediments recovered from the Labrador Sea. Gombos (1982) defined a zonation for the high southern latitudes. Although several of the species recorded by Gombos (1982) occur in Leg 105 sediments, their stratigraphic usefulness is uncertain. On the basis of cosmopolitan species, Fenner (1984) proposed a Paleogene low-latitude zonation for the Atlantic, Pacific, and Indian oceans. The upper part of this zonation was modified by Barron $(1985 \mathrm{~b})$ for use in the equatorial Pacific Ocean. The Paleo- 
gene zonation of Fenner (1984) is used for Leg 105 studies when possible.

\section{Radiolarians}

No standard radiolarian zonation can be used to date sediments from the Labrador Sea. Biostratigraphic ranges for a few relatively cosmopolitan species seen at Site 647 can be obtained from the standard low-latitude radiolarian zonation (Riedel and Sanfilippo, 1978), although many of the zonal indicators are exclusively tropical species and are missing in high-latitude sediments. The zonation based on high-latitude radiolarian assemblages recovered from the Norwegian Sea during DSDP Leg 38 and ODP Leg 104 could not be applied to the Labrador Sea because of the absence of stratigraphic marker species.

Cycladophora davisiana occurs in Pliocene-Pleistocene sediments around the world, particularly in high-latitude regions (Bjørklund, 1976; Barron et al., 1980; Sakai, 1980) and was used to date sediments recovered by Leg 105 . The first occurrence of this species within the early Pliocene is not well dated.

The standard low-latitude radiolarian zonation is given in Figure 8 .

\section{Dinoflagellate Cysts}

The few Neogene dinocyst stratigraphies that have been calibrated to magnetostratigraphy and/or calcareous nannofossil stratigraphy include those of Manum (1976; Norwegian-Greenland Sea), Edwards (1985; Rockall Plateau), Bujak (1984; Bering Sea and North Pacific; see Fig. 8), Costa and Downie (1979; Rockall Plateau), Brown and Downie (1985b, Goban Spur), Harland (1979a; Bay of Biscay; see Fig. 8), Aksu and Mudie (1985; Arctic Ocean), and Mudie (in press, central North Atlantic; see Fig. 8). Comparison of these dinocycst stratigraphies shows differences in the composition of assemblages for a given time interval. This reflects the strong relationships that exist between environmental conditions (notably temperature and salinity) and assemblage composition. Therefore, previously established dinocyst stratigraphies may not be applicable at Leg 105 sites. For this reason, the maximum stratigraphic range of dinocysts is used to provide age estimates.

For the Paleogene, various zonal schemes exist though many are based on shelf assemblages, and no single scheme is used extensively. Zones tabulated in Figure 8 are based on correlations in Berggren et al. (1986a) and Williams and Bujak (1985). Based upon calcareous nannofossil correlations, these schemes are indirectly tied to the chronostratigraphy. For example, the schemes of Bujak et al. (1980) and Chateauneuf (1980) are constrained by some nannofossil datums (Aubry, 1985), though a number of zonal boundaries are correlated using dinocysts or are unconstrained. Such zonal boundaries are represented by dotted lines in Figure 8. Other important studies include Costa and Downie (1979) and Brown and Downie (1985a and b), which have been tied to magnetostratigraphy and various biostratigraphic schemes. Williams and Bujak (1985) compiled ranges of numerous taxa correlated with nannofossil and planktonic foraminiferal zones. These correlations are not in all cases rigorously proven by Williams and Bujak (1985) but are nevertheless considered useful for preliminary age estimates.

\section{Shipboard Preparation Techniques}

\section{Calcareous Nannofossils}

Smear slides were prepared from all samples for light-microscope analysis of nannofossils. In addition, a few samples were prepared for scanning electron microscope (SEM) study. Smear slides were prepared and examined for nannofossils from corecatcher samples and some additional core samples. Because of the absence of nannofossils in most samples, a second prepara- tion process, involving concentration of silt-size particles by suspension settling, was followed for core-catcher samples from Cores 105-645B-1X and 105-645B-5X through 105-645B-9X. Nannofossils were not observed in most of these samples. Selected samples (105-645E-70R, CC, 105-645E-73R, CC, 105645D-20R, CC, 105-645D-18R, CC, and 105-0645E-35R, CC) were processed for SEM study using ultrasonic disaggregation and suspension settling.

\section{Foraminifers}

About $10 \mathrm{~cm}^{3}$ of sediment was taken from each core catcher, dispersed in water with about $20 \mathrm{~cm}^{3}$ of $1 \%$ Calgon, passed through a wet sieve having a $63-\mu \mathrm{m}$ screen, and oven dried. Foraminifers were studied in the $>63-\mu \mathrm{m}$ fraction according to standard micropaleontological procedures. Samples with large detrital debris required splitting to obtain a workable sample size. All specimens from the split were hand picked and mounted on reference slides.

\section{Diatoms}

Each sample (about $5 \mathrm{~cm}^{3}$ of sediment) was processed in a beaker using hydrogen peroxide $\left(\mathrm{H}_{2} \mathrm{O}_{2}\right)$ and hydrochloric acid $(\mathrm{HCl})$ and heated to speed the chemical reaction. Upon completion of the reaction, the beaker was filled with distilled water. After $1 \frac{1}{2} \mathrm{hr}$, the water was decanted and the beaker was refilled with distilled water. This procedure was repeated until a $\mathrm{pH}$ of about 6 was achieved. A few drops of the residue were mounted between slides using Hyrax mounting medium. The strewn slides were examined at a magnification of $700 \times$, and species identifications were verified at a magnification of $1250 \times$.

\section{Radiolarians}

Strewn slides were prepared and examined for radiolarians from each core catcher and occasionally from other stratigraphic intervals as well. Sediment samples were treated with $30 \%$ $\mathrm{H}_{2} \mathrm{O}_{2}, 10 \% \mathrm{HCl}$, and boiled in $1 \%$ Calgon. Incompletely disaggregated samples were cleaned in a Bransonic model B-22-4 ultrasonic cleaner for intervals of a few seconds up to a maximum of $2 \mathrm{~min}$. Enough of the $>44-\mu \mathrm{m}$ fraction needed to make a moderately dense preparation was mounted in Canada Balsam on a standard glass microscope slide. A minimum of $100 \mathrm{~mm}^{2}$ (or $\sim 5000$ grains) were scanned for the presence of radiolarians on each slide.

\section{Palynology}

Palynological samples were normally prepared using the following techniques: (1) sieving at $10 \mu \mathrm{m}$ to eliminate fine silts and clays, $(2)$ repeated $\mathrm{HCl}(10 \%)$ treatment to eliminate carbonates, and (3) repeated HF $(52 \%)$ treatment to destroy silicate minerals. The samples are then mounted on glass slides with glycerine gel for examination under the microscope. Because of safety restrictions aboard JOIDES Resolution, it was impossible to use HF routinely. Therefore, the aforementioned method was modified and consists of the following: (1) disaggregation by boiling in a $1 \%$ solution of Calgon, (2) sieving at $20 \mu \mathrm{m}$, (3) $\mathrm{HCl}(10 \%)$ treatment, and (4) separation by swirling or gravity settling in distilled water. Using this technique, we may have lost some small and dense microfossils; the on-board palynological results may not represent the total palynomorph content of the sediments. For this reason, most samples were reprocessed on shore using variations of the first method described. An aliquot volume of exotic pollen (Eucalyptus globulus or Lycopodium) suspension was then added to each sample to calculate the absolute frequency of palynomorphs.

\section{PALEOMAGNETICS}

Paleomagnetic studies of the sediments cored on ODP Leg 105 included both remanence and rock-magnetic measurements. 
Pass-through and discrete-sample remanence measurements were conducted using the shipboard fluxgate spinner and the threeaxis cryogenic magnetometer. Rock-magnetic measurements consisted of initial magnetic-susceptibility measurements, which were made both on archive half sections of the cores and on standard paleomagnetic discrete samples, using the Bartington susceptibility meter.

We used three different sampling techniques for taking discrete samples. Two of the methods involved pressing a die or plastic box into the sediment to extract an oriented $5-7-\mathrm{cm}^{3}$ cube of undisturbed sediment. A sampling device, which uses a template to orient the stainless steel die that is pressed into the sediment, was employed at Site 645. The template is cut so that two specimens can be taken side by side. The sediment is extruded out of the die into a plastic box. This method is limited to $5-\mathrm{cm}^{3}$ samples. We decided to measure larger samples and to take the samples from the center of the core; therefore, we quit using this sampling device and instead simply pressed oriented $7-\mathrm{cm}^{3}$ plastic cubes directly into the sediment. When the sediment became too indurated to sample in this manner, we sampled it by drilling $10-\mathrm{cm}^{3}$ minicores from segments of the working half, using a diamond drill bit and a drill press. In friable and fragile samples, we cut $7-\mathrm{cm}^{3}$ cubes from the working half of the core, using a diamond saw.

Samples were taken at nominal $1.5-\mathrm{m}$ intervals (one per core section). In the high-sedimentation-rate material cored on ODP Leg $105(30-120 \mathrm{~m} / \mathrm{m} . \mathrm{y}$.$) , this sampling interval proved ade-$ quate to resolve short polarity chronozones ( $>50,000 \mathrm{yr}$ long).

\section{Measurements}

Two magnetometers were used to measure the direction and magnitude of remanent magnetizations of Leg 105 materials. We used the Molspin fluxgate spinner magnetometer to measure discrete samples. The three-axis pass-through cryogenic magnetometer was used to measure archive halves of the cores.

Progressive demagnetization studies of pilot samples were carried out using a Schonstedt single-axis, alternating-field (AF) demagnetizer. Pilot samples were progressively demagnetized at 50 - to $100-O e$ increments up to 900 Oe or until the remaining magnetization intensities measured less than $10 \%$ of the natural remanent magnetization (NRM) values. The results of the progressive demagnetization studies were plotted using vector endpoint diagrams. On the basis of these results, the remaining samples were demagnetized at the appropriate peak field level.

Measurements made using the three-axis pass-through cryogenic magnetometer were limited to the archive halves of the cores because the magnetizations were too high to be measured given the total volume of the whole core, because the whole cores were commonly split or bowed, rendering them too large to pass through the instrument, and because the working half of the cores could not be subjected to AF demagnetization.

Comparisons of demagnetizations using the pass-through $\mathrm{AF}$ demagnetizer, which is in line with the pass-through cryogenic magnetometer, with results using the Schonstedt single-axis demagnetizer indicate that the pass-through system works well and produces similar results over the range of from 0 to $90 \mathrm{Oe}$. No evidence of an anhysteric remanent magnetization was observed using the pass-through system. We, therefore, routinely partly demagnetized the archive halves at 50-80 Oe, resulting in a much cleaner record. Comparison to the NRM results indicates that the demagnetizer works well.

Data reduction consisted of reducing the cryogenic magnetometer output files using the Crunch program written by Jim Ogg. These were then plotted using the shipboard graphics package and with the Coreplot program written by Jim Brooks.

\section{Rock-Magnetic Methods}

Rock-magnetic analyses provide useful methods of characterizing the magnetic mineralogy and granulometry of sediments cored during Leg 105 . Only magnetic-susceptibility measurements were conducted during the cruise. Further analyses will be performed on shore.

Magnetic-susceptibility measurements were performed using a Bartington magnetic-susceptibility meter and a bridge linked to an Epson computer. Measurements were made using both whole-core (archive half) and discrete samples. The whole-core susceptibility meter oscillates at a base frequency of $146.9 \mathrm{~Hz}$. This frequency can be altered to 2,4 , and 8 times this value. Whole-core measurements were made principally at the $2 \times$ range. Whole-core susceptibility measurements were commonly performed at $5-\mathrm{cm}$ intervals from the top of the hole to the depth of the base of the Brunhes Chronozone, corresponding approximately to the age of oxygen-isotope stage 19 .

The standard used for whole-core measurements was unreliable. Prepared on shore by pouring $\mathrm{Mn}_{2} \mathrm{O}_{3}$ into a $25-\mathrm{cm}$-long cylinder, this standard visibly compacted during the cruise, thereby altering its density and susceptibility.

Discrete-sample measurements were performed on all samples taken for paleomagnetic studies. A few samples, where core disturbance was high, were taken strictly for rock-magnetic analyses.

The results given in the site chapters are from shipboard measurements and have not been corrected for sample mass, volume, or standard. Therefore, these results must be viewed with caution. Interpretation of the susceptibiity and other rockmagnetic data will await further shore-based analyses.

\section{GEOCHEMISTRY}

\section{Hydrocarbon Gases}

For safety considerations, gas samples were taken by vacutainer from gas pockets in the cores. These gas samples were analyzed for composition of methane (C1) and ethane (C2), using a Hewlett Packard 5890 Gas Chromatograph (GC) equipped with a packed column (Poropak Q). Because of changes in GC conditions during the early part of the leg, the data should be interpreted cautiously. The absolute values of $\mathrm{C} 1$ and $\mathrm{C} 2$ may be incorrect, so the $\mathrm{C} 1, \mathrm{C} 2$, and $\mathrm{C1} / \mathrm{C} 2$ records should be used only as rough estimates of the composition of the gas.

\section{Total Organic Carbon}

Total organic carbon (TOC) was determined by two methods:

1. TOC was determined by difference between the total carbon (from the Perkin Elmer 240C Elemental Analyzer) and the inorganic carbon (from the Coulometrics Carbonate Carbon Apparatus).

2. TOC was directly determined from the carbonate-free residues by the elemental analyzer. For this, carbonate was dissolved by hot hydrochloric acid treatment and the carbonatefree residues were washed and dried. The TOC values obtained by this procedure (i.e., TOC' in weight percentage of the carbonate-free sediment fraction) were transferred into TOC values (weight percentage of the bulk sediment samples) using the equation

$$
\text { TOC }=\frac{100-(8.334 \times \mathrm{TC})}{\left(100 / \mathrm{TOC}^{\prime}\right)-8.334},
$$

where TC is the total carbon in weight percentage of the bulk sediment as determined by the elemental analyzer. The TOC val- 
ues produced by this method agree well with data obtained by the LECO elemental analyzer methods (Fig. 10; R. Stein, pers. comm., 1985).

\section{Rock-Eval Procedure}

The source character and maturity of organic matter in selected sediment samples were determined with the shipboard Rock Eval II Plus TOC pyrolysis instrument, which uses the process described by Espitalié et al. (1977). This procedure yielded the following parameters: hydrogen index $\left(\mathrm{mg} \mathrm{HC} / \mathrm{g} \mathrm{C}_{\mathrm{org}}\right.$ ), oxygen index ( $\mathrm{mg} \mathrm{CO}_{2} / \mathrm{g} \mathrm{C}_{\text {org }}$ ), and $\mathrm{T}_{\max }\left({ }^{\circ} \mathrm{C}\right)$.

\section{Calcium Carbonate}

Percentage of carbonate was determined by three different methods: the carbonate-bomb technique (Müller and Gastner, 1971), the use of a Coulometrics Carbonate Carbon Apparatus, and the difference between total carbon and total organic carbon measurements (see "Total Organic Carbon" section, this chapter). The percentage of carbonate values were calculated as percentage of calcium carbonate. The carbonate values of samples analyzed by the carbonate bomb and by the difference between total carbon and total organic carbon agree well, except for very low carbonate values (Fig. 11).

\section{Interstitial Water}

Interstitial-water samples were extracted from $10-\mathrm{cm}$ wholeround sections (minicores) by a hydraulic press, as modified and described by Manheim (1966). The water samples were then filtered through $0.45-\mu \mathrm{m}$ Metricel filters and stored in acid-cleaned glass vials. Immediately following retrieval, alkalinity and $\mathrm{pH}$

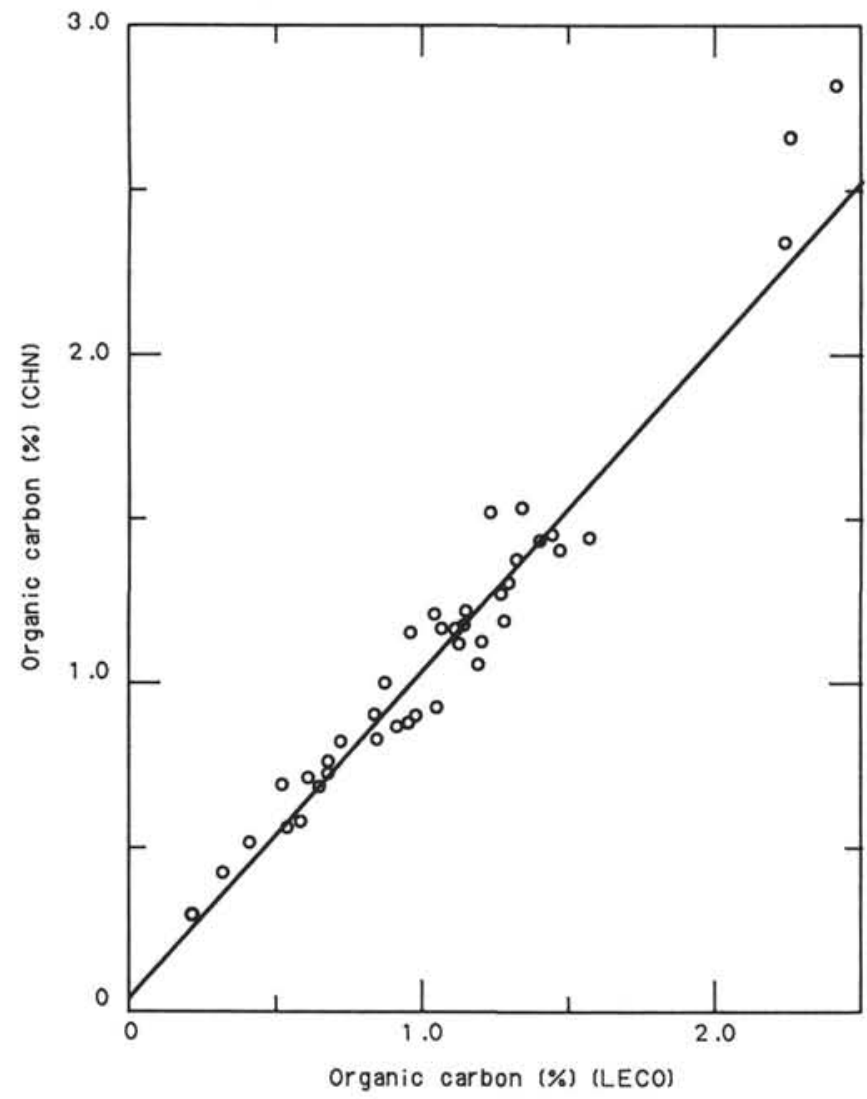

Figure 10. Correlation between organic carbon values determined by the CHN analyzer and organic carbon values determined by LECO ( R. Stein, pers. comm, 1985).

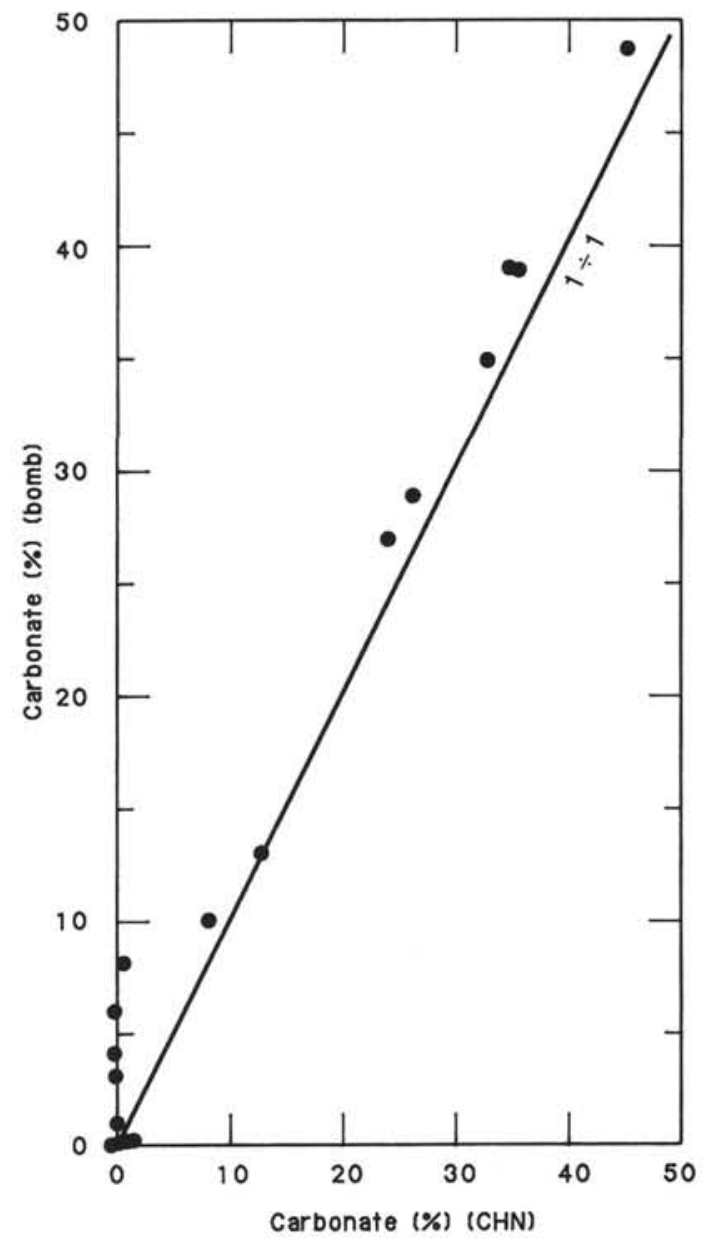

Figure 11. Correlation between carbonate values determined by the carbonate bomb and carbonate values determined by the $\mathrm{CHN}$ analyzer.

measurements were simultaneously carried out, using a Metrohm titrator with a Brinkman combination $\mathrm{pH}$ electrode. Calcium, magnesium, and chlorinity concentrations were determined volumetrically by standard shipboard titration methods, as reported by Gieskes (1974). Salinity measurements were conducted with a refractometer. Sulfate analyses were carried out by ion chromatography, using procedures outlined in shipboard manuals.

\section{X-RAY DIFFRACTION ANALYSIS}

\section{Clay-Fraction Samples}

Five samples were analyzed by X-ray diffraction (XRD) to identify the main mineralogical composition of the clay fraction. Sample preparation was simple, and the number of samples small; therefore, only general conclusions are possible.

A 2- $\mathrm{cm}^{3}$ aliquot of wet sample was suspended in a dilute Calgon solution. After settling for $1 \mathrm{hr}$, the $<2$-m fraction was decanted using a pipette. A few drops were transferred to a small glass slide. After drying at about $20^{\circ} \mathrm{C}$, the sample was scanned from $2^{\circ} 2 \theta$ to $60^{\circ} 2 \theta$ in steps of $0.02^{\circ}$ at a counting time of $1 \mathrm{~s}$. No glycolation, heat treatment, and so forth were performed.

\section{Bulk Samples}

For XRD measurements, subsamples of the physical-properties samples were taken, ground, and prepared as randomly oriented, pressed powder slides. Scans were run between $2^{\circ}$ and 
$60^{\circ} 2 \theta$, using a scanning speed of $1.2 \% \mathrm{~min}$. For evaluation of the diffractograms, the peak areas of the illite $(10 \AA)$, kaolinite plus chlorite $(7.1 \AA)$, quartz $(3.34 \AA), \mathrm{K}$-feldspar $(3.24 \AA)$, plagioclase (3.21-3.18 $\AA$ ), calcite (3.03 $\AA)$, and dolomite $(2.89 \AA)$ lattice reflections were determined. Peak intensities were then "weighted" by multiplying the following intensity factors: quartz, 1 ; feldspars, 1 ; carbonates, 0.7 ; illite, 12 ; and kaolinite/chlorite, 3 . These intensity factors are based on the results of measurements of standard mixtures (quartz/feldspar, quartz/calcite, quartz/illite, calcite/dolomite, and calcite/feldspar mixtures). In general, these in-house factors differ from those compiled from more extensive data by Cook et al. (1975) and are based on only a few measurements of standard mixtures. A more detailed study is necessary to determine more precisely the intensity factors valid for this particular XRD equipment. The possibility of somewhat inaccurate intensity factors has to be considered when interpreting the percentage values of the minerals; that is, the data should be used only as rough estimates of the mineralogy of the bulk sediment. These percentage values were calculated by dividing the weighted peak-area value of a single mineral phase by the sum of the weighted peak areas of all the seven aforementioned mineral phases.

\section{PHYSICAL-PROPERTY PROCEDURES}

A thorough discussion of physical properties is presented by Boyce (1973 and 1976) with respect to equipment, methods, errors, correction factors, and problems related to coring disturbance. Only a brief review of methods employed on Leg 105 is given here.

The Gamma Ray Attenuation Porosity Evaluator (GRAPE), described in detail by Boyce (1976), was used to measure continuously the wet-bulk density of material in core sections more than $50 \mathrm{~cm}$ long. Aluminum standards were run before each core was run. Computer programs were developed to produce files from which digital output of depth and density could be obtained. The transformed data files were used in plotting routines devised to produce whole-core records scaled to the size of core barrel sheets.

After GRAPE analysis, the cores were allowed to equilibrate to room temperature for approximately $4 \mathrm{hr}$. Probes connected to a Thermcon- 85 unit, interfaced with a PRO-350 computer, were inserted in the sediment through holes drilled in the liner, and the thermal drift was monitored. Once the temperature stabilized, the coefficient of thermal conductivity was determined as a function of the change in resistance in the probes induced by temperature changes over a 6 -min interval. Conductivity determination was stopped when the sediment became too stiff to allow insertion of the probes.

Undrained shear strength was determined using a Wykeham Farrance vane apparatus operating at a rotation rate of $90 \% \mathrm{~min}$ with a $1.28 \times 1.28-\mathrm{cm}$ blade. The vane rotated with its axis parallel to bedding on a split core. Measurements were discontinued at the depth below which the sediment was so stiff that it fractured as the vane was inserted.

Compressional-wave velocity was calculated from determination of the traveltime of a $500-\mathrm{kHz}$ acoustic signal through a measured sediment thickness, using a Hamilton Frame velocimeter and Tektronix DC 5010 counter/timer system. Traveltimes were determined perpendicular to bedding on 1 - to 2 -cm-thick quarter-round samples, which had been carefully cut from the core. Measurements made on soft sediment and friable material produced spurious results because the samples commonly deformed when placed in the velocimeter frame.

Wet-bulk density, water content, porosity, void ratio, and grain density were determined for 5- to $15-\mathrm{g}$ "chunk" samples. Values were corrected for an assumed interstitial-water salinity of $35 \mathrm{ppt}$ by estimating the weight of seawater from the weight of evaporated water, according to the technique of Hamilton (1971). Definitions used for the index properties are (1) wet-bulk density $\left(\mathrm{g} / \mathrm{cm}^{3}\right)=$ weight of wet sediment $\div$ volume of wet sediment; (2) water content (dry weight $\%$ ) $=100 \times$ weight of seawater $\div$ weight of dry sediment; $(3)$ porosity $(\%)=100 \times$ volume of seawater $\div$ volume of wet sediment; (4) void ratio = volume of seawater $\div$ volume of dry sediment; and (5) grain density $\left(\mathrm{g} / \mathrm{cm}^{3}\right)=$ weight of dry sediment $\div$ volume of dry sediment. Dry-sediment weight and volume used in the definitions are corrected by subtracting the estimated weight and volume of salt. Weight measurements were made with a counterbalance system consisting of two Scientech 202 electronic balances interfaced with a Hewlett-Packard $86 \mathrm{~B}$ computer. Volume determinations were made with a Quantachrome Penta-Pycnometer, which is a helium-displacement pycnometer. Wet measurements were made immediately after core splitting. Dry weight and volume determinations were made after the samples had dried for $24 \mathrm{hr}$ at $105^{\circ} \mathrm{C}$ and had subsequently cooled in a dessicator.

Basement-rock samples were treated differently than the sediment samples. Only GRAPE wet-bulk density and compressional velocity were determined for these samples. Velocity measurements were made on (1) whole- or half-round samples as soon as possible after the cores arrived on deck and (2) minicores, $2.5 \mathrm{~cm}$ in diameter, which were taken from split sections after the cores were curated. Curatorial procedures required for basalt involve drying the samples, which may increase the measured velocities by as much as $8 \%$ (Hay, Sibuet, et al., 1984). The minicores were placed in seawater after cutting in an attempt to resaturate the rocks and minimize the drying-induced error. Following the velocity measurement, wet-bulk density of the minicore samples was determined by the GRAPE 2-min count technique (Boyce, 1976).

Downhole temperature measurements conducted on Hole 646A used a Von Herzen heat flow probe, which fits into the HPC coring shoe. Measurements were recorded in the probe, then transferred to the VAX computer systems after completion of the run. Three measurements were made in Cores 105-646A$4 \mathrm{H}, 105-646 \mathrm{~A}-7 \mathrm{H}$, and $105-646 \mathrm{~A}-10 \mathrm{H}$ at depths of $35.8,64.8$, and $93.8 \mathrm{~m}$.

\section{Calculation of Accumulation Rates}

Accumulation rates of the material cored during Leg 105 were calculated using the method described by Müller and Suess (1979), in which accumulation rate (C) in $\mathrm{gm} \mathrm{cm}^{2} \mathrm{k} . \mathrm{y} .^{-1}$ is given by

$$
\mathrm{C}=\frac{(\mathrm{wt} \% \mathrm{C}) \rho \mathrm{S}}{100},
$$

where $\mathrm{C}$ is the accumulation rate of the component, wt $\%$ is the weight percentage of the component, and $\rho$ is the dry-bulk density of the sediment in $\mathrm{g} \mathrm{cm}^{-3}$ calculated as

$$
\rho=(\text { wet-bulk density }) \frac{\phi}{100}\left(1.01 \mathrm{~g} \mathrm{~cm}^{-3}\right),
$$

in which $\phi=\%$ porosity and $1.01 \mathrm{~g} \mathrm{~cm}^{-3}$ is the average density of marine pore waters. $\mathrm{S}$ is the bulk sedimentation rate in $\mathrm{cm}$ k.y. ${ }^{-1}$.

\section{DOWNHOLE LOGGING}

Downhole logging directly determines properties of in-situ formations adjacent to the borehole. After coring is completed at a hole, a tool string is lowered downhole on a coaxial cable, and each of several tools in the tool string continuously monitor some property of the adjacent borehole. Of the dozens of different tool strings commonly used in the petroleum industry, 
two were selected for Leg 105: the Schlumberger LSS/DIL/ $\mathrm{MCD} / \mathrm{GR}$ and the Schlumberger GST/CNTG/NGT.

\section{Log Types}

The physical principles and properties of the Schlumberger LSS/DIL/MCD/GR and GST/CNTG/NGT tools are described in previous shipboard reports and many publications (Schlumberger, 1972; Serra, 1984; Bateman, 1985; Borehole Research Group, 1985) and are not repeated here in any detail.

The long-spaced sonic (LSS) tool has two transducers and two receivers, permitting measurements of sonic traveltime over distances of 8,10 , and $12 \mathrm{ft}$. Two logs are recorded: the shorter spaced DT log measures the traveltime difference for the 2 -ft interval between the 8 - and 10 -ft transducer/receiver pairs, while the longer-spaced DTL log uses the 10- and 12-ft pairs. Traveltimes are based on a simple first-break threshold criterion. Waveforms were recorded during logging upward but have not been analyzed yet.

The DIL part of the tool records three resistivity logs having different depths of penetration: the spherically focussed log (SFL) penetrates $<50 \mathrm{~cm}$ into the formation, the medium-induction Laterolog (ILM) penetrates about 1-2 m, and the deepinduction Laterolog (ILD) penetrates about $2 \mathrm{~m}$. The resistivity logs respond primarily to formation porosity (assuming absence of hydrocarbons); some lithologic response also occurs associated with bound water in clays.

The caliper (MCD) is a three-arm (bowspring) device that measures hole diameter. It is utilized primarily for quality control and environmental correction of other types of logs.

The gamma-ray (GR) tool measures the natural gamma-ray emissions of the formation. Radioactive decay of potassium, uranium, and thorium contribute to the measured signal, but the potassium contribution is typically dominant. Traditionally considered a sand/shale indicator, the tool is more correctly described as an indicator of the relative proportion of quartz and carbonate to clay minerals because it responds to mineralogy rather than to grain size. Potassium feldspars can dominate the gamma-ray response but are typically minor compared with potassium-bearing clays.

The gamma-ray spectrometry tool (GST) is a neutron-activation tool. A pulsed neutron accelerator bombards the adjacent formation with high-energy neutrons and then measures the timevarying energy spectrum of gamma rays produced by the bombardment. Each element has a characteristic spectral response to neutron bombardment. The GST detects six elements (silicon, calcium, iron, chlorine, hydrogen, and sulfur) and estimates the proportion of the total measured spectrum attributable to each element. Raw count rates for each element are therefore less useful than ratios of count rates among the six elements.

Four diagnostic elemental-yield ratios were routinely determined by Schlumberger during data acquisition. The lithologyindicator ratio (LIR), the ratio of silicon counts to the sum of silicon plus calcium counts, can be used as a semiquantitative indicator of the relative abundance of quartz and biogenic silica to calcite. The presence of clay minerals and dolomite make interpretation of the LIR less straightforward. The iron-indicator ratio (IIR), the ratio of iron counts to silicon plus calcium counts, can be a good measure of total iron concentration unless the amount of aluminum in clays varies substantially downhole. The porosity-indicator ratio (PIR), the ratio of hydrogen counts to silicon plus calcium counts, indirectly measures the total amount of free water (pore spaces) plus bound water (in clay minerals) by detecting hydrogen abundance. The salinity-indicator ratio (SIR), the ratio of chlorine counts to hydrogen counts, might more properly be considered a chlorinity-indicator ratio. Because bound water in clay minerals may contain hydrogen and an unpredictable amount of chlorine, the SIR works best in formations lacking clay minerals.

A major advantage of the GST is that it works well through pipe, unlike the LSS/DIL/MCD/GR. Of course, the varying thickness of pipe affects iron counts, and careful data reduction is required. A major disadvantage is the slow logging speed $(150-200 \mathrm{~m} / \mathrm{hr})$ and the multiple passes required for accurate characterization of the energy spectrum. The GST is normally run alone and through casing. On Leg 105, however, the GST was run in open-hole, in combination with the CNTG and NGT tools, replacing the lithodensity tool (LDT) typically run with these two tools. This combination was used because time was not sufficient to run both the GST and the LDT/CNTG/NGT and because LDT quality is severely degraded by borehole rugosity.

The neutron tool (CNTG) uses a radioactive source to bombard the formation with neutrons. Neutrons with both thermal and epithermal energy states are captured by nuclei in the formation. Each capture is accompanied by gamma-ray emission, having an energy state dependent on the type of atom; the CNTG measures the amount of capture resulting from hydrogen. In hydrocarbon-free formations, the CNTG, therefore, measures total water content of the formation, including both water in pore spaces and bound water in clay minerals.

The natural gamma-ray tool (NGT) is somewhat similar to the standard gamma-ray (GR) tool, in that both measure the natural gamma radiation emitted by formation rocks during radioactive decay of potassium, uranium, and thorium. Unlike the GR tool, which measures only total gamma rays, the NGT analyzes the spectral distribution of the gamma rays to provide accurate concentrations for the three elements. Potassium and thorium concentrations and their ratio are useful in determining type of clay minerals present. Uranium often accumulates along faults or fractures; thus uranium concentration can indicate a fracture.

None of the aforementioned logs is invariably reliable. All can be affected to some extent by hole conditions (Table 2), such as changes in hole diameter, extensively caved intervals (washouts), and shale fracturing and alteration. The optimum logs to use in any hole may, therefore, depend on expected or observed hole conditions, as well as on scientific goals. Further, parts of many logs may require editing before their use in analysis and interpretation.

\section{Log Applications}

Downhole logging on Leg 105 had two primary applications: (1) establishing a continuous tie between seismic time and core depth, and (2) determining lithology, mineralogy, and porosity as a function of depth.

The seismic-core tie is the necessary link between regional seismic data and our detailed knowledge of the geology at a drill site. Before site results can be extrapolated laterally from one location to an entire region, seismic traveltimes corresponding to core depths must be established. Velocimeter measurements on core samples can help in this conversion from time to depth, but the most reliable and detailed conversion is accomplished by using a continuous sonic log such as the LSS. With both a sonic log and an estimate of the seismic wavelet, a synthetic seismogram can be generated and compared with the seismic section across the site. Because lithology and porosity vary laterally across a region, isolating their effects on the velocity of individual formations is also desirable. The seismic-core tie is perhaps the most important contribution of downhole logging to the objectives of Leg 105.

Although the logging tools used on Leg 105 are remarkably different physically and in the formation characteristics they measure, all respond to one or more of three fundamental prop- 
Table 2. Log sensitivity to hole conditions and log applications.

\begin{tabular}{|c|c|c|c|c|c|c|c|}
\hline \multirow[b]{2}{*}{$\log$} & \multicolumn{3}{|c|}{$\begin{array}{l}\text { Minimum quality of } \\
\text { hole conditions } \\
\text { tolerated by log }\end{array}$} & \multirow{2}{*}{$\begin{array}{l}\text { Seismic }^{a} \\
\text { core tie }\end{array}$} & \multirow[b]{2}{*}{ Lithology ${ }^{a}$} & \multirow[b]{2}{*}{ Porosity $^{\mathrm{a}}$} & \multirow{2}{*}{$\begin{array}{c}\text { Logging } \\
\text { Speed }\end{array}$} \\
\hline & Good & Fair & Poor & & & & \\
\hline Sonic & & $\mathrm{X}$ & & 3 & 2 & 3 & 600 \\
\hline 12-channel sonic & & $\mathrm{X}$ & & 4 & 2 & 4 & 180 \\
\hline Deep resistivity & & & $\mathrm{X}$ & 2 & 2 & 4 & 600 \\
\hline SFL & & $\mathrm{X}$ & & 2 & 2 & 4 & 600 \\
\hline GR spectrometry & & $\mathrm{x}$ & & 1 & 4 & 0 & 300 \\
\hline Gamma ray & & $\mathrm{x}$ & & 1 & 4 & 0 & 600 \\
\hline GST & & & $\mathrm{x}$ & $i$ & 4 & 1 & $100-200$ \\
\hline Density & & $\mathrm{x}$ & & 3 & 2 & 3 & 300 \\
\hline Neutron & $\mathrm{x}$ & & & 1 & 2 & 4 & 300 \\
\hline
\end{tabular}

${ }^{a}$ Usefulness of log for indicated purpose: (1) marginal, (2) fair, (3) good, (4) very good.

erties: lithology, porosity, and pore fluids (Table 2). In ODP holes, hydrocarbons are seldom present in substantial quantities; thus, the pore fluid is simply seawater. Increasing the number of logs run causes a corresponding increase in the degree to which minor lithologic variations can be determined. Even a full suite of logs cannot compete with detailed core analysis of a single sample. Thus, the primary value of logs for lithology and porosity determination is that these variables are measured quickly and continuously over the entire logged interval. Both lithology and porosity determinations are, of course, most valuable in intervals of poor or disturbed core recovery. Porosity determination through logs has the additional asset of measuring in-situ porosity before the core is disturbed by drilling or by core expansion because of pressure release.

\section{Log Analysis}

During logging, incoming data were observed in real time on a monitor oscilloscope and simultaneously recorded on digital tape in the Schlumberger logging unit. After logging, this tape was copied from 800-bpi to 1600-bpi tape on the shipboard Vax computer system. The 1600 -bpi tape was then read by the Masscomp computer system in the downhole logging laboratory aboard ship and reformatted to a file format compatible with the Terralog log-interpretation software package. Rather than being a "black box," Terralog is an interactive system consisting of many log-manipulation and plot options. Thus, the log analysis and interpretation varied in duration and procedure for each site. Preliminary log interpretation was carried out on board ship; more detailed analysis and interpretation were undertaken after the cruise, using a companion system in the Borehole Research Laboratory of Lamont-Doherty Geological Observatory.

\section{OBTAINING SAMPLES}

Potential investigators wishing to obtain samples should refer to the ODP-NSF Sample-Distribution Policy. Sample-request forms may be obtained from the Curator, Ocean Drilling Program, 1000 Discovery Drive, College Station Texas, 77840. Requests must be as specific as possible: include site, hole, core, section, interval within a section, and volume of sample required.

\section{REFERENCES}

Aksu, A. E., and Mudie, P. J., 1985. Magnetostratigraphy and palynology demonstrate at least 4 million years of Arctic Ocean sedimentation. Nature, 318:280-283.

Aubry, M. P., 1985. Northwestern European Paleogene magnetostratigraphy, biostratigraphy and paleogeography: calcareous nannofossil evidence. Geology, 13(3):198-202.

Baldauf, J. G., 1985. Cenozoic diatom biostratigraphy and paleoceanography of the Rockall Plateau region, North Atlantic, Deep Sea
Drilling Project Leg 81. In Roberts, D. G., Schnitker, D., et al., Init. Repts. DSDP, 81: Washington (U.S. Govt. Printing Office), 439478.

in press. Diatom biostratigraphy of the middle and high latitude North Atlantic Ocean, Deep Sea Drilling Project Leg 94. In Kidd, R., Ruddiman, W., et al., Init. Repts. DSDP, 94: Washington (U.S. Govt. Printing Office).

Baltuck, M., von Huene, R., and Aubouin, J., 1985. Introduction and explanatory notes. In von Huene, R., Aubouin, J., et al., Init. Repts. DSDP, 84: Washington (U.S. Govt. Printing Office), 5-19.

Barron, J. A., 1980. Lower Miocene to Quaternary diatom biostratigraphy of Leg 57, off Northeastern Japan, Deep Sea Drilling Project. In Langseth, M., Okada, H., et al., Init. Repts. DSDP, 56, 57 (Pt. 2): Washington (U.S. Govt. Printing Office), 641-685.

Barron J., 1985a. Miocene to Holocene planktic diatoms. In Bolli, H. M., Saunders, J. B., and Perch-Nielsen, K. (Eds.), Biostratigraphy by Marine Plankton: Cambridge (Cambridge Univ. Press), 763-809.

Barron, J. A., 1985b. Late Eocene to Holocene diatom biostratigraphy of the equatorial Pacific Ocean, Deep Sea Drilling Project Leg 85. In Mayer, L., Theyer, F., et al., Init. Repts. DSDP, 85: Washington (U.S. Govt. Printing Office), 413-456.

Barron, J. A., Harper, H. E., Jr., Keller, G., Reynolds, R. A., Sakai, T., Shaffer, B. L., and Thompson, P. R. 1980. Biostratigraphic summary of the Japan Trench transect, Legs 56 and 57, Deep Sea Drilling Project. In Langseth, M., Okada, H., et al., Init. Repts. DSDP, 56 , 57 (Pt.1): Washington (U.S. Govt. Printing Office), 505-520.

Barron, J. A., Keller, G., and Dunn, D., in press. A multiple microfossil biochronology for the Miocene. In CENOP Spec. Pap., Geol. Soc. Am. Mem.

Bateman, R. M., 1985. Log Quality Control: Boston (IHRDC).

Benedeck, P. M., and Müller, C., 1974. Nannoplankton-PhytoplanktonKorrelation im Mittel- und Ober-Oligozdn von NW-Deutschland. $N$. Jahrb. Geol. Paleontol., Monatsh., 385-397.

Berggren, W. A., 1972. Cenozoic biostratigraphy and paleobiogeography of the North Atlantic. In Laughton, A. S., Berggren, W. A., et al., Init. Repts. DSDP, 12: Washington (U.S. Govt. Printing Office), $965-1001$.

1973. The Pliocene timescale: calibration of planktonic foraminiferal and calcareous nannoplankton zones. Nature, 24:391-397. 1977. Late Neogene planktonic foraminiferal biostratigraphy of the Rio Grande Rise (South Atlantic). Mar. Micropaleontol., 2: 265-313.

Berggren, W. A., and Schnitker, D., 1983. Cenozoic marine environments in the North Atlantic and Norwegian-Greenland Sea. In Bott, M.H.P., Saxov, S., Talwani, J., and Thiede, J. (Eds.), Structure and Development of the Greenland-Scotland Ridge-New Methods and Concepts. NATO Conference Series IV(8):495-548.

Berggren, W. A., Aubry, M. P., and Hamilton, N., 1983. Neogene magnetobiostratigraphy of Deep Sea Drilling Project Site 516 (Rio Grande Rise, South Atlantic). In Barker, P. F., Johnson, D. J., Carlson, R. L., et al., Init. Repts. DSDP, 72: Washington (U.S. Govt. Printing Office), 675-714.

Berggren, W. A. Kent, D. V., and Flynn, J. J., 1986a. Paleogene geochronology and chronostratigraphy. In Snelling, N. J., (Ed.), Geochronology and the Geologic Time Scale: Geol. Soc. London Mem., 211-250. 
Berggren, W. A., Kent, D. V., and van Couvering, J. A., 1986b. Neogene geochronology and chronostratigraphy. In Snelling, N. J., (Ed.), Geochronology and the Geologic Time Scale: Geol. Soc. London Mem., 141-195.

Bjørklund, K. R., 1976. Radiolaria from the Norwegian Sea, Leg 38 of the Deep Sea Drilling Project. In Talwani, M., Udintsev, G., et al., Init. Repts. DSDP, 38: Washington (U.S. Govt. Printing Office), 1101-1168.

Blow, W. H., 1969. Late middle Eocene to Recent planktonic foraminiferal biostratigraphy. In Bronnimann, P., and Renz, H. H., (Eds.), Proc., First Int. Conf. Planktonic Microfossils: Leiden (E. J. Brill), 689-702.

Boersma, A., 1985. Oligocene benthic foraminifers from North Atlantic sites: benthic foraminifers as water-mass indexes in the North and South Atlantic. In Bougault, H., Cande, S. C., et al., Init. Repts. $D S D P, 82$ : Washington (U.S. Govt. Printing Office), 611-628.

Borehole Research Group, 1985. Wireline Logging Manual, Ocean Drilling Program: New York (Lamont-Doherty Geological Observatory).

Boyce, R. E., 1973. Appendix I. physical properties-methods. In Edgar, N. T., Saunders, J. B., et al., Init. Repts. DSDP, 15: Washington (U.S. Govt. Printing Office), 1115-1128.

Boyce, R. E., 1976. Definitions and laboratory techniques of compressional sound velocity parameters and wet-water content, wet-bulk density, and porosity parameters by gravimetric and gamma ray attenuation techniques. In Schlanger, S. O., Jackson, E. D., et al., Init. Repts. DSDP, 33: Washington (U.S. Govt. Printing Office), 931958.

Brown, S., and Downie, C., 1985a. Dinoflagellate cyst biostratigraphy of late Paleocene and early Eocene sediments from Holes 552, 553A, and 555, Leg 81, Deep Sea Drilling Project (Rockall Plateau). In Roberts, D. G., Schnitker, D., et al., Init. Repts. DSDP, 81: Washington (U.S. Govt. Printing Office), 565-579.

1985b. Dinoflagellate cyst stratigraphy of Paleocene to Miocene sediments from the Goban Spur (Sites 548-550, Leg 80). In de Graciansky, P. C., Poag, C. W., et al., Init. Repts. DSDP, 80 (Pt. 1): Washington (U.S. Govt. Printing Office), 643-651.

Bujak, J. P., 1976. An evolutionary series of late Eocene dinoflagellate cysts from southern England. Mar. Micropaleontol., 1:101-117.

1979. Proposed evolution of the dinoflagellates Rhombodinium and Gochtodinium. Micropaleontology, 25:308-324.

Bujak, J. P., and Davies, E. H., 1983. Modern and Fossil Peridiniineae. Am. Assoc. Strat. Palynol., Contribu. Ser. 13.

Bujak, J. P., Downie, C., Eaton, G. L., and Williams, G. L., 1980. Dinoflagellate cysts and acritarchs from the Eocene of southern England. Spec. Pap. Palaeontol., 24:1-100.

1984. Cenozoic dinoflagellate cysts and acritarchs from the Bering Sea and northern North Pacific, DSDP Leg 19. Micropaleontology, 30:180-212.

Bukry, D., 1973. Low-latitude coccolith biostratigraphic zonation. In Edgar, N. T., Saunders, J. B., et al., Init. Repts. DSDP, 15: Washington (U.S. Govt. Printing Office), 685-704.

Chateauneuf, J.-J., 1980. Palynostratigraphie et paléoclimatologie de l'Eoéne supérieur et de l'Oligocéne du Bassin de Paris (France): Paris (Bureau de Recherches Géologiques et Miniéres) Mémoire 116.

Chateauneuf, J.-J., and Gruas-Cavagnetto, C., 1978. Les zones de Wetzeliellaceae (Dinophyceae) du Bassin de Paris. Bull. Bureau de Recherches Géologiques et Miniéres. Second Ser., Sect. IV, 2-1978, 5993.

Cook, H. E., Johnson, P. D., Matti, J. C., and Zemmels, I., 1975. Methods of sample preparation and X-ray diffraction data analysis, X-ray mineralogy laboratory, Deep Sea Drilling Project, University of California, Riverside. In Hayes, D. E., Frakes, L. A., et al., Init. Repts. DSDP, 28: Washington (U.S. Govt. Printing Office), 9991008 .

Costa, L. I., and Downie, C., 1976. The distribution of the dinoflagellate Wetzeliella in the Palaeogene of north-western Europe. Paleontology, 19:591-614

1979. Cenozoic dinocyst stratigraphy of Sites 403 to 406 (Rockall Plateau), IPOD, Leg 48. In Montadert, L., Roberts, D. G., et al., Init. Repts. DSDP, 48: Washington (U.S. Govt. Printing Office), 513-529.

Dean, W. E., Leinen, M., and Stow, D.A.V., 1985. Classification of deep-sea, fine-grained sediments. J. Sed. Pet., 55:250-256.

Doerenkamp, A., Jardine, S., and Moreau, P., 1976. Cretaceous and Tertiary palynomorph assemblages from Banks Island and adjacent areas (N.W.T.). Bull. Can. Pet. Geol., 24:372-417.
Dzinoridze, R. N., Jousé, A. P., Koroleva-Golikova, G. S., Kozlova, G. E., Nagaeva, G. S., Petrushevskaya, M. G., and Strelnikova, N. I., 1978. Diatom and radiolarian Cenozoic stratigraphy, Norwegian Basin; DSDP Leg 38. In Talwani, M., Udintsev, G., et al., Init. Repts. DSDP, Supp. Vols. 38-41: Washington (U.S. Govt. Printing Office), 289-427.

Eaton, G. L., 1971. A morphogenetic series of dinoflagellate cysts from the Bracklesham Beds of the Isle of Wight, Hampshire, England. Proc., Second Planktonic Conf., 1:355-379.

1976. Dinoflagellate cysts from the Bracklesham Beds (Eocene) of the Isle of Wight, southern England. Bull. Brit. Mus., London (Natural History), and Geology, 26:227-332.

Edwards, L. E., 1985. Miocene dinocysts from Deep Sea Drilling Project Leg 81, Rockall Plateau, eastern North Atlantic Ocean. In Roberts, D. G., Schnitker, D., et al., Init. Repts. DSDP, 81: Washington (U.S. Govt. Printing Office), 581-594.

Eldholm, O., Thiede, J., Taylor, E., et al. in press. Proc., Init. Repts. (Pt. A.) ODP, 104.

Espitalié, J., Madec, M., and Tissot, B. P., 1977. Source rock characterization method for petroleum exploration. Proc., Ninth Ann. Offshore Techn. Conf., 439-448.

Fenner, J., 1984. Eocene-Oligocene planktic diatom stratigraphy in the low-latitudes and high southern latitudes. Micropaleontology, 30; 319-342.

Folk, R. L., 1980. Petrology of Sedimentary Rocks: Austin, Tex. (Hemphill Publishing Co.).

Gealy, E. L., Winterer, E. L., and Moberly, R. M., Jr., 1971. Methods, conventions, and general observations. In Winterer, E. L., Riedel, W. R., et al., Init. Repts. DSDP, 7 (Pt. 1): Washington (U.S. Govt. Printing Office), 9-26.

Geroch, S., and Nowak, W., 1984. Proposal of zonation for the late Tithonian-late Eocene based upon arenaceous foraminifera from the outer Carpathians, Poland. In Benthos 1983, Proc., Second Int. Sym. Benthic Foraminifera, 225-239.

Gieskes, J. M., 1974. Interstitial water studies, Leg 25. In Simpson, E.S.W., Schlich, R., et al., Init. Repts. DSDP, 25: Washington (U.S. Govt. Printing Office), 361-394.

Goll, R. M., 1978. Five Trissocyclid radiolaria from Site 338. In Talwani, M., Undintsev, G., et al., Init. Repts. DSDP, Supp. to Vols. 38-41: Washington (U.S. Govt. Printing Office), 177-191.

Gombos, A. M., Jr., 1982. Early and middle Eocene diatom evolutionary events. Bacillaria, 5:225-242.

Hamilton, E. L., 1971. Prediction of in situ acoustic and elastic properties of marine sediments. Geophysics, 36:266-284.

Harland, R., 1979a. Dinoflagellate biostratigraphy of Neogene and Quaternary sediments at Holes 400/400A in the Bay of Biscay (Deep Sea Drilling Project Leg 48). In Montadert, L., Roberts, D. G., et al., Init. Repts. DSDP, 48: Washington (U.S. Govt. Printing Office), 531-545.

1979b. The Wetzeliella (Apectodinium) homomorpha plexus from the Palaeocene/earliest Eocene of North-West Europe. Proc., Fourth Int. Palynol. Conf., 2:59-70.

Hay, W. W., Sibuet, J.-C., et al., 1984. Introduction and explanatory notes, Deep Sea Drilling Project Leg 75. In Hay, W. W., Sibuet, J.C., et al., Init. Repts. DSDP, 75 (Pt. 1): Washington (U.S. Govt. Printing Office), 3-25.

Koizumi, I., 1973. The late Cenozoic diatoms of Sites 183-193, Leg 19, Deep Sea Drilling Project. In Creager, J. S., Scholl, D. W., et al., Init. Repts. DSDP, 19: Washington (U.S. Govt. Printing Office), 805855.

Manheim, F. T., 1966. A hydraulic squeezer for obtaining interstitial water from consolidated and unconsolidated sediments. U.S. Geol. Surv. Prof. Paper 550-C, 256-261.

Manum, S. B., 1976. Dinocysts in Tertiary Norwegian-Greenland Sea sediments (Deep Sea Drilling Project Leg 38) with observations on palynomorphs and palynodebris in relation to environment. In Talwani, M., Udintsev, G., et al., Init. Repts. DSDP, 38, Washington (U.S. Govt. Printing Office), 897-919.

Martini, E., 1971. Standard Tertiary and Quaternary calcareous nannoplankton zonation. In Farinacci, A. (Ed.), Proc., Second Planktonic Conf., (Vol. 2): Rome (Edizioni Tecnoscienza), 739-777.

Matthews, D. J., 1939. Table of Velocity of Sound in Pore Water and in Seawater: London (Admiralty, Hydrographic Dept.).

Miller, K. G., Audrey, M.-P., Khan, M. J., Melillo, A. J., Kent, D. V., and Berggren, W. A., 1985. Oligocene to Miocene biostratigraphy, 
magnetostratigraphy, and isotopic stratigraphy of the western North Atlantic. Geology, 13:257-261.

Miller, K. G., Curry, W. B., and Ostermann, D. R., 1985. Late Paleogene (Eocene to Oligocene) benthic foraminiferal oceanography of the Goban Spur region, Deep Sea Drilling Project Leg 80. In de Graciansky, P. C. Poag, C. W., et al., Init. Repts. DSDP, 80 (Pt. 1): Washington (U.S. Govt. Printing Office), 505-538.

Mudie, P. J., in press. Palynology and dinoflagellate biostratigraphy of DSDP Leg 94, Sites 607 and 611, North Atlantic Ocean. In Rudiman, W. T., Kidd, R., et al., Init. Repts. DSDP, 94: Washington (U.S. Govt. Printing Office).

Müller, C. 1976. Tertiary and Quaternary calcareous nannoplankton in the Norwegian-Greenland Sea, DSDP Leg 38. In Talwani, M., Udintsev, G., et al., Init. Repts. DSDP, 38: Washington (U.S. Govt. Printing Office), 823-856.

Müller, G., and Gastner, M., 1971. The "Karbonate-Bombe," a simple device for the determination of the carbonate content in sediments, soils and other materials. N. Jahrb. Mineral. Monatsch., 10:466469.

Müller, P. J., and Suess, E., 1979. Productivity, sedimentation rate and sedimentary organic matter in the oceans - I. organic carbon preservation, Deep-Sea Research, 26:1347-1362.

Murray, J. W., 1985. Paleogene and Neogene benthic foraminifers from Rockall Plateau. In Roberts, D. G., Schnitker, D., et al., Init. Repts. DSDP, 81: Washington (U.S. Govt. Printing Office), 725-732.

Norris, G., in press. Systematic and stratigraphic palynology of Eocene to Pliocene strata in Imperial Nuktak C-22 well, Mackenzie Delta region, District of Mackenzie, N.W.T., Geol. Surv. Can. Bull.

Okada, H., and Bukry, D., 1980. Supplementary modification and introduction of code numbers to the low-latitude coccolith-biostratigraphic zonations (Bukry, 1973, 1975). Mar. Micropaleontol., 5: 321-325.

Riedel, W. R., and Sanfilippo, A., 1978. Stratigraphy and evolution of tropical Cenozoic radiolarians. Micropaleontology, 23:61-96.

Roberts, D. G., Backman, J., Morton, A. C., and Keene, J. B., 1984. Introduction and explanatory notes, Leg 81, Deep Sea Drilling Project. In Roberts, D. G., Schnitker, D., et al., Init. Repts. DSDP, 81: Washington (U.S. Govt. Printing Office), 5-28.

Rouse, G. E., 1977. Paleogene palynomorph ranges in western and northern Canada. In Elsik, W. C. (Ed.), Contributions to Stratigraphic Palynology (Vol.1): Am. Assoc. Strat. Palynol. Contribu. Ser. 5A:48-65.
Sakai, T., 1980. Radiolarians from Sites 434, 435, and 436, northwest Pacific, Leg 56, Deep Sea Drilling Project. In Langseth, M., Okada, H., et al., Init. Repts. DSDP, 56, 57 (Pt. 2): Washington (U.S. Govt. Printing Office), 695-733.

Schlumberger Ltd., 1972. Log Interpretation, Vol. 1-Principles: New York (Schlumberger Ltd.).

Schrader, H.-J., and Fenner, J., 1976. Part 1. Norwegian Sea Cenozoic diatom biostratigraphy. In Talwani, M., Udintsev, G., et al., Init. Repts. DSDP, 38: Washington (U.S. Govt. Printing Office), 921962.

Serra, O., 1984, Fundamentals of Well Log Interpretation (Vol. 1). The Acquisition of Logging Data: Amsterdam (Elsevier).

Snyder, S. W., and Walters, V. J., 1985. Cenozoic planktonic foraminiferal biostratigraphy of the Goban Spur region, Deep Sea Drilling Project Leg 80. In de Graciansky, P. C., Poag, C. W., et al., Init. Repts. DSDP, 80 (Pt. 1): Washington (U.S. Govt. Printing Office) 439-472.

Supko, P., Ross, D. A., and Neprochnov, Y. P., 1978. Introduction and explanatory notes, Leg 42B, Deep Sea Drilling Project. In Ross, D. A., Neprochnov, Y. P., et al., Init. Repts. DSDP, 42 (Pt. 2): Washington (U.S. Govt. Printing Office), 3-15.

Tjalsma, R. C., 1983. Eocene to Miocene benthic foraminifers from DSDP Site 516, Rio Grande Rise, South Atlantic. In Barker, P. F., Johnson, D. J., Carlson, R. L., et al., Init. Repts. DSDP, 72: Washington (U.S. Govt. Printing Office), 731-756.

Townsend, H. A., 1985. The paleomagnetism of sediments acquired from the Goban Spur on Deep Sea Drilling Project Leg 80. In de Graciansky, P. C., Poag, C. W., et al., Init. Repts. DSDP, 80 (Pt. 1): Washington (U.S. Govt. Printing Office), 389-414.

Verdenius, J. G., and van Hinte, J. E., 1983. Central Norwegian-Greenland Sea: Tertiary arenaceous foraminifera, biostratigraphy and environment. In Verdenius, J. G., van Hinte, J. E., and Fortuin, A. R. (Eds.), Proc., First Workshop Arenaceous Foraminifera: Norway (Continental Shelf Institute), 173-224.

Williams, G. L., and Bujak, J. P., 1985. Mesozoic and Cenozoic dinoflagellates. In Bolli, H. M., Saunders, J. B., and Perch-Nielsen, K. (Eds.), Plankton Stratigraphy: Cambridge (Cambridge Univ. Press.), 847-964.

Young, F. G., and McNeil, D. H., 1984. Cenozoic stratigraphy of the MacKenzie Delta, Northwest Territories. Geol. Surv. Can. Bull., $336: 1-63$. 